\title{
Acute Myeloid Leukemia Stem Cells: The Challenges of Phenotypic Heterogeneity
}

\author{
Marlon Arnone ${ }^{1}$, Martina Konantz ${ }^{1}\left(\mathbb{D}\right.$, Pauline Hanns ${ }^{1}$, Anna M. Paczulla Stanger ${ }^{2}$, \\ Sarah Bertels ${ }^{2}$, Parimala Sonika Godavarthy ${ }^{2}$, Maximilian Christopeit ${ }^{2}$ (D) \\ and Claudia Lengerke $1,2, *$ D \\ 1 Department of Biomedicine, University of Basel and University Hospital Basel, Hebelstrasse 20, \\ 4031 Basel, Switzerland; marlon.arnone@unibas.ch (M.A.); martina.konantz@unibas.ch (M.K.); \\ pauline.hanns@unibas.ch (P.H.) \\ 2 Internal Medicine II, Hematology, Oncology, Clinical Immunology and Rheumatology, \\ Department for Internal Medicine, University Hospital Tübingen, Otfried-Müller-Str. 10, \\ 72076 Tübingen, Germany; anna.stanger@med.uni-tuebingen.de (A.M.P.S.); \\ sarah.bertels@med.uni-tuebingen.de (S.B.); Parimala.Godavarthy@med.uni-tuebingen.de (P.S.G.); \\ Maximilian.Christopeit@med.uni-tuebingen.de (M.C.) \\ * Correspondence: claudia.lengerke@med.uni-tuebingen.de; Tel.: +49-7071-29-82915
}

Received: 30 October 2020; Accepted: 10 December 2020; Published: 12 December 2020

Simple Summary: Relapse after apparent remission remains a major cause of death in patients with acute myeloid leukemia (AML). On the cellular level, leukemia relapse is considered to emerge from subpopulations of therapy-resistant leukemic stem cells (LSC). Identification and targeting of LSC are thus most important goals for AML treatment. However, AML and their LSC are highly heterogeneous. Here, we review the current knowledge on AML LSC identification and targeting via surface antigens with a focus on heterogeneity among different AML subgroups and genetic backgrounds.

\begin{abstract}
Patients suffering from acute myeloid leukemia (AML) show highly heterogeneous clinical outcomes. Next to variabilities in patient-specific parameters influencing treatment decisions and outcome, this is due to differences in AML biology. In fact, different genetic drivers may transform variable cells of origin and co-exist with additional genetic lesions (e.g., as observed in clonal hematopoiesis) in a variety of leukemic (sub)clones. Moreover, AML cells are hierarchically organized and contain subpopulations of more immature cells called leukemic stem cells (LSC), which on the cellular level constitute the driver of the disease and may evolve during therapy. This genetic and hierarchical complexity results in a pronounced phenotypic variability, which is observed among AML cells of different patients as well as among the leukemic blasts of individual patients, at diagnosis and during the course of the disease. Here, we review the current knowledge on the heterogeneous landscape of AML surface markers with particular focus on those identifying LSC, and discuss why identification and targeting of this important cellular subpopulation in AML remains challenging.
\end{abstract}

Keywords: acute myeloid leukemia; leukemic stem cells; cellular heterogeneity; markers; relapse

\section{Introduction}

Acute myeloid leukemia (AML) is a devastating, rapidly-evolving disease characterized by an abnormal proliferation of poorly-differentiated cells which impairs normal hematopoiesis. AML patients suffer from cytopenia associated with recurrent infections, anemia, easy bleeding, and other manifestations [1] and show highly variable responses to therapy and survival rates. Notably, a major cause of disease progression and relapse is the persistence of therapy-resistant, clonogenic leukemic subpopulations: the leukemic stem cells (LSC) [2]. 
In 1994, John Dick and colleagues were the first to prove the existence of human LSC in an in vivo experimental model. Human $\mathrm{CD} 34^{+}$leukemic cells were shown to repopulate the bone marrow (BM) of severe combined immunodeficient (SCID) mice, while CD34- leukemic blasts remained non-leukemogenic $[3,4]$. These $\mathrm{CD}^{+} 4^{+}$cells responsible for leukemia initiation and maintenance were termed LSC. Nowadays, they are documented as cells with enhanced capacities to selectively escape chemotherapy treatments [5] as well as immune surveillance [6], thus leading to disease relapse after therapy, a major cause of death in these patients. Since AML is highly heterogeneous with respect to genetic alterations, epigenetics, and leukemia cell of origin, it is not surprising that considerable heterogeneity is also observed among surface markers of AML cells and their LSC [2], making immunological targeting of LSC a constant challenge [7-9].

\section{Leukemic Stem Cells and Healthy Stem/Progenitor Cells}

Hematopoiesis is organized hierarchically with a minor subset of hematopoietic stem cells (HSC) giving rise to all blood cells during the lifespan of an individual. HSC must balance regenerative requirements (which naturally involve cell division and differentiation) with the need to protect their own genomic integrity by reducing cell division. In order to achieve this, HSC undergo highly complex fine-tuned interactions with the BM microenvironment and interact with several other cell types (e.g., osteoblasts, stromal cells, endothelial cells, adipocytes, and neural cells) via soluble factors, biophysical forces, and cell-mediated interactions [10]. Similarly, LSC also reside and are influenced by the so-called BM niche, which sustains their quiescence and protects them from genotoxic stress [11,12].

AML is also organized hierarchically and contains subpopulations of LSC that share functional and molecular properties with their cells of origin, the healthy hematopoietic stem and progenitor cells (HSPC) [4,13-15]. Consistent with a close relationship between these two cell types, molecules expressed on healthy HSPC, i.e., CD34, were also reported to identify LSC [16]. Functionally, the CD34 family encompasses podocalyxin and endoglycan proteins and is considered to regulate cell differentiation, adhesion, trafficking, and proliferation [17]. CD34 is expressed on the vast majority of HSC, but rare CD34- HSC giving rise to CD34+ ${ }^{+}$HSPC have also been reported [16].

In 2016, the LSC17 gene expression score was defined as the molecular LSC hallmark that predicts outcome and treatment resistance in patients with AML [18]. Among the genes highlighted in the LSC17 score were e.g., CD34 and the G protein-coupled receptor GPR56, a surface protein involved in cell adhesion which was also described to mark healthy HSC $[16,19]$. However, great phenotypic heterogeneity is observed in AML LSC and a wide range of surface markers has been found to identify LSC in only some, but not all AML (e.g., CD93, TIM3, CD44, CD123, etc. [9,20-26]).

\section{The Relevance of Immunomodulatory Proteins for LSC Detection}

Interestingly, a variety of antigens involved in LSC identification are in fact involved in immunological processes (Figure 1, Table 1). This suggests that LSC and non-LSC may have different interactions with the immune system. This notion has been substantiated by recent work from our research group demonstrating that LSC selectively escape immune surveillance by suppressing surface expression of NKG2D ligands (NKG2DL) [6]. When compared to corresponding non-stem leukemic blasts from the same patients, LSC lack expression of such ligands for activating NKG2D receptors on natural killer (NK) cells thereby evading NK-mediated lysis. In several AML patient samples of heterogeneous genetic backgrounds, lack of NKG2DL surface expression robustly distinguished LSC from other non-stem leukemic cells [6].

Other examples of immunomodulatory proteins involved in LSC identification (Figure 1) include the immunoglobulin superfamily member CD96, a molecule expressed on healthy T and natural killer cells with known inhibitory roles on NK cells [27], TIM-3 (T cell immunoglobulin mucin-3), a homeostasis-maintaining molecule of the immune system expressed on the surface of $\mathrm{CD} 4^{+} \mathrm{T}$ type 1 helper cells (Th1) and CD8 ${ }^{+} \mathrm{T}$ type 1 cytotoxic cells, monocytes/macrophages, dendritic cells (DC), and mast cells [28], the lectin protein CLL-1 regulating cell activation during inflammation 
and CD32, an immune-activating immunoglobulin $F_{C}$ receptor family member showing broad expression on hematopoietic cells [29,30]. Furthermore, the interleukin-2 receptor alpha-chain CD25 commonly expressed on activated and regulatory $\mathrm{T}$ cells, but also found on resting memory T cells [31], and CD123, the interleukin-3 receptor (IL-3R) alpha chain, which is part of the IL-3R system that includes interleukin-5 receptor (IL-5R) and granulocyte-macrophage colony stimulating factor receptor (GM-CSFR), are also found on LSC. While interleukin 2 is important for survival, activation, and proliferation of T cells, the IL-3R system influences proliferation, survival, and differentiation of hematopoietic cells and is involved in immunity and inflammatory response by specifically binding respective ligands (IL-3, IL-5, and GM-CSF) [32].

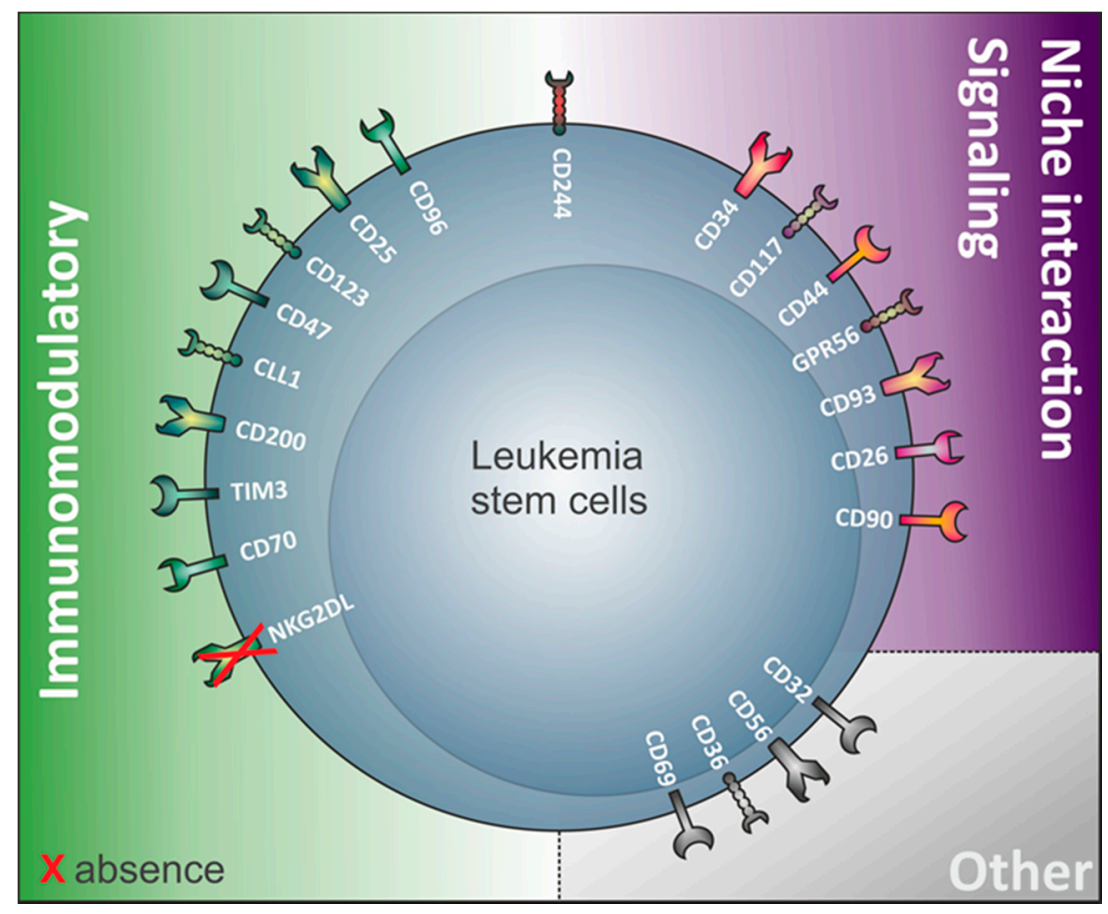

Figure 1. Surface antigens involved in leukemic stem cells (LSC) identification. Several surface proteins involved in LSC identification are involved in immune processes (e.g., TIM-3, CLL-1, CD47 ... ) or interactions with the bone marrow niche (e.g., GPR56, CD44 ... ).

Last but not least, the immunoglobulin-like and integrin-associated protein CD47 was identified as a novel AML LSC marker [33]. CD47 serves as a ligand of signal regulatory protein-1 (SIRP-1) and thereby functions as a “don't eat me" signal, protecting LSC from macrophage phagocytosis [34].

\section{LSC Surface Markers in CD34 Expressing Compared to CD34 Non-Expressing AML}

The HSPC antigen CD34 is a well-established LSC surface marker in AML. However, approximately $30 \%$ of AML cases lack robust CD34 expression among leukemic blasts, perhaps because they originate from healthy CD34- hematopoietic progenitors. The LSC compartment of these AML cases (in the following termed "CD34 non-expressing AML") is less well studied but was shown to also contain CD34 negative LSC [18,35-37]. We have therefore decided to separately review LSC markers reported for CD34 expressing and non-expressing AML subtypes and their LSC (See Table 1).

\subsection{CD34 Expressing AML Contain CD34 ${ }^{+}$LSC}

AML LSC were first experimentally defined as subpopulations of CD34 ${ }^{+}$AML cells [3]. In follow-up studies, LSC were then further enriched in this subpopulation by selection for the lack of CD38 expression, an antigen induced upon myeloid differentiation in healthy hematopoietic cells [4] functioning as a 
NAD+ glycohydrolase [38] or co-expression of the tyrosine phosphatase CD45RA [35,39,40], a CD45 isoform which plays a role in $\mathrm{T}$ cell signaling [41]. Upon isolation and injection into immunodeficient mice, LSC positive or negative for CD45RA and/or CD38 were able to induce leukemia, indicating that LSC can also be found in populations that phenotypically resemble more mature cells, such as common myeloid or granulomonocytic progenitors (CMP/GMP) $[25,35,39,40]$. CD45RA has been shown to potently enrich/isolate LSC compared to markers such as CD123, CCL-1, or the pan-myeloid antigen CD33 [39], however here only the $\mathrm{CD} 34^{+} / \mathrm{CD} 38^{-}$compartment was investigated regarding CD45RA expression. Therefore, LSC might have been missed in $\mathrm{CD} 34^{-}$or $\mathrm{CD} 38^{+}$subpopulations in these studies.

Interestingly, CD45RA+ LSC were also documented to express CD123. In two independent studies, $\mathrm{CD} 4^{+} / \mathrm{CD} 38^{-} / \mathrm{CD} 4 \mathrm{RA}^{+} / \mathrm{CD} 123^{+}$or $\mathrm{CD} 4^{+} / \mathrm{CD} 38^{+} / \mathrm{CD} 4 \mathrm{RA}^{+} / \mathrm{CD} 23^{+}$cells were leukemogenic, highlighting the potential of CD123 as a marker capable of identifying and enriching LSC $[35,40]$. In line, recent studies showed that high percentages of $\mathrm{CD} 34^{+} / \mathrm{CD} 38^{-} / \mathrm{CD} 123^{+}$cells at diagnosis of AML could indicate poor prognosis in patients [42]. A retrospective analysis of more than 100 patients under 65 years of age with de novo AML indicated that higher percentages of $\mathrm{CD} 34^{+} / \mathrm{CD} 38^{-} / \mathrm{CD} 123^{+}$ leukemia cells at diagnosis associate with enhanced probability of resistance to intensive chemotherapy and shorter disease-free survival [42]. A prospective study including 444 elderly AML patients confirmed the prognostic significance of $\mathrm{CD} 34^{+} / \mathrm{CD} 38^{-} / \mathrm{CD} 123^{+}$at diagnosis for the clinical outcome of patients receiving intensive chemotherapy, but not for those treated with hypomethylating agents only [43]. Since CD123 is likely not expressed on healthy HSC [44,45], it might represent an attractive candidate for immunological targeting of LSC.

Proteins of the so-called multi drug resistant (MDR) group, such as MDR1, BCRP, MDR3, MRP1 (also known as CD9), or LRP [46], are also heterogeneously expressed in AML with higher expression levels in $\mathrm{CD} 34^{+} \mathrm{CD} 38^{-} \mathrm{CD} 123^{+}$LSC. Expression of the tetraspanin protein CD9 nicely enables the discrimination of LSC from HSC. However, CD9 is also detectable on multipotent and lymphoid primed multipotent progenitors [47] and on cells from solid tumors (e.g., lung, breast, thyroid, and pancreas cancer (stem) cells $[48,49])$.

Finally, contradictory data exists on the expression of CD90, a multifunction cell surface glycoprotein and its involvement in LSC biology [50-52]. As such, it was e.g., documented that CD90 is absent on most AML blasts [52] despite its function in the maintenance of HSC both in vitro and in vivo [53], and cells lacking surface expression of this antigen were able to form colonies and lead to leukemia onset in patient-derived xenograft (PDX) assays [52].

\subsection{CD34 Non-Expressing AML and Their LSC}

The so-called "CD34 non-expressing AML" is known to completely lack or harbor only very low percentages of $\mathrm{CD} 34^{+}$subpopulations. Taussig and colleagues demonstrated that in such AML, LSC are comprised within $\mathrm{CD} 34^{-}$subpopulations. Among these, $\mathrm{CD} 34^{-} / \mathrm{CD} 38^{+}$as well as $\mathrm{CD} 34^{-} / \mathrm{CD} 38^{-}$ subpopulations induced leukemia [37]. The existence of CD34- LSC was separately demonstrated by Sarry and colleagues [35]. Especially when present at very low numbers, CD34 ${ }^{+}$cells from such "CD34 non-expressing AML" may lack leukemogenic properties because they in fact represent contaminating cells that are of a non-malignant nature. This notion is supported by their capacities to regenerate normal hematopoiesis in xenotransplanted mice [37].

The existence of CD34 non-expressing AML (and CD34- LSC) suggests that these cells may derive from more differentiated $\left(\mathrm{CD} 34^{-}\right)$healthy hematopoietic cells. They might undergo leukemic transformation by acquisition of mutations in genes aberrantly conferring self-renewal and stem-like properties, such as mutations in nucleophosmin NPM1, which are commonly found in CD34 non-expressing AML, thereby leading to aberrant activation of Hox gene expression [54].

Further enrichment within CD34- ${ }^{-}$LSC subpopulations can be provided by analyses of surface expression levels of the transmembrane tyrosine kinase cKIT (CD117) and the natural killer cell receptor 2B4, also known as CD244 (See Table 1). cKIT+ cells alone showed various level of engraftment, but cKIT and CD244 double positive cells robustly engrafted in all AML cases [36]. Among healthy 
hematopoietic cells, cKIT and CD244 are expressed by GMPs. In line, CD34- LSC from NPM1 mutated AML were shown to harbor both a GMP and a stemness signature [36]. Accordingly, Goardon and colleagues demonstrated that LSC can derive from more committed progenitors regardless of their CD34 expression [40]. Furthermore, CD32 expression was shown to enrich LSC when applied in conjunction with CD38 in CD34 non-expressing AML [7]. Finally, although being expressed at higher levels in CD34-non-expressing AML, CLL-1 expression can distinguish LSC in both CD34-expressing and non-expressing AML [55,56]. Of note, CLL-1 is apparently not expressed on healthy HSC [24]. Further underscoring the complexity of these heterogeneous cellular systems, there are also data reporting that CD34- ${ }^{-}$SC may develop in vivo into serially transplantable CD34 ${ }^{+}$and CD34- cells [36], which in secondary recipients may give rise to both subpopulations.

\subsection{Review of Markers Capturing LSC in AML Samples Regardless of Their CD34 Expression}

In the following section, we review the most robust markers that have been described to enrich LSC across all AML, regardless of their CD34 expression.

\subsubsection{Absence of NKG2D Ligands}

Recently, we have shown that LSC suppress NKG2DL expression on their surface to avoid NK-mediated killing [6]. NKG2DL ${ }^{-}$but not corresponding NKG2DL ${ }^{+}$AML cells from the same patients were demonstrated to induce leukemia in PDX models as well as in in vivo syngeneic mouse leukemia models, despite the fact that both subpopulations contained similar leukemia-specific mutations.

When compared to NKG2DL ${ }^{+}$cells, NKG2DL ${ }^{-}$cells showed enriched PARP1 expression [6]. Importantly, suppression of PARP1 could induce NKG2DL expression on previously NKG2DL ${ }^{-}$LSC, making them sensitive to NK-mediated recognition and killing. Consistently, treatment with PARP1 inhibitors followed by allogeneic NK cell transplantation could eradicate primary human LSC in PDX assays in vivo. This is the first study to provide functional information on the relationship between stem cells and NK cell immune evasion in AML. 
Table 1. Non-comprehensive list of human markers that can be found on LSC and their (potential) expression on the cell surface of other healthy blood cells. Highlighted in grey are the markers expressed on the cell surface of LSC from both CD34-expressing and non-expressing acute myeloid leukemia (AML). In white: markers only demonstrated to play roles in LSC from CD34 expressing AML. N.D: Not described/MPP: multipotential progenitor/MEP: megakaryocyte- erythroid progenitor).

\begin{tabular}{|c|c|c|c|c|c|c|}
\hline Antigen & $\begin{array}{l}\text { Percentage of AML Patients } \\
\text { Expressing the Marker }\end{array}$ & $\begin{array}{l}\text { Expression on } \\
\text { Non-LSC }\end{array}$ & $\begin{array}{l}\text { Expression on } \\
\text { HSC }\end{array}$ & $\begin{array}{l}\text { Expression on Other Healthy } \\
\text { Blood Cells }\end{array}$ & Function in Healthy Conditions & References \\
\hline CLL-1 & 92 & Yes & No & $\begin{array}{l}\text { Monocytes, granulocytes, } \\
\text { CMP, GMP }\end{array}$ & $\begin{array}{l}\text { Modulates the activation state of cells during } \\
\text { inflammation processes }\end{array}$ & $\begin{array}{l}\text { Bakker et al. } 2004 \text { [57] } \\
\text { Jiang et al. } 2018 \text { [58] } \\
\text { Daga et al. } 2019 \text { [55] } \\
\text { Marshall et al. } 2006 \text { [29] }\end{array}$ \\
\hline CD9 & 40 & Yes & No & $\begin{array}{l}\text { Monocytes, macrophages, } \\
\text { granulocytes, DC, endothelial } \\
\text { cells, B, T, and NK cells }\end{array}$ & Cell migration, adhesion, activation, & $\begin{array}{l}\text { Brosseau et al. } 2018 \text { [59] } \\
\text { Touzet et al. } 2019 \text { [47] } \\
\text { Paprocka et al. } 2017 \text { [46] }\end{array}$ \\
\hline CD25 & $10-25$ & Yes & No & $\mathrm{T}$ cells and regulatory $\mathrm{T}$ cells & Important role for $\mathrm{T}$ cells survival & $\begin{array}{l}\text { Saito et al. } 2010 \text { [60] } \\
\text { Kageyama et al. } 2018 \text { [61] } \\
\text { Triplett et al. } 2012 \text { [31] }\end{array}$ \\
\hline CD26 & N.D & Yes & No & $\mathrm{T}, \mathrm{B}, \mathrm{NK}$, and myeloid cells & $\begin{array}{l}\text { T cell activation and proliferation, } \\
\text { cell adhesion, metabolism }\end{array}$ & $\begin{array}{l}\text { Herrmann et al. } 2020 \text { [25] } \\
\text { Klemann et al. } 2016 \text { [62] }\end{array}$ \\
\hline CD32 & 35 & Yes & No & Monocytes, B and T cells & Immune cell activation & $\begin{array}{l}\text { Saito et al. } 2010[60] \\
\text { Anania et al. } 2019[30]\end{array}$ \\
\hline CD33 & 88 & Yes & Yes & $\begin{array}{l}\text { Myeloid cells, lymphocytes, } \\
\text { NK cells, MPP, GMP, MEP }\end{array}$ & $\begin{array}{l}\text { Modulates inflammatory and immune responses by } \\
\text { reducing tyrosine kinase dependent pathways }\end{array}$ & $\begin{array}{l}\text { Ehninger et al. } 2014 \text { [63] } \\
\text { Liu et al. } 2007 \text { [64] } \\
\text { Laszlo et al. 2014 [65] } \\
\text { Haubner et al. } 2017 \text { [24] }\end{array}$ \\
\hline CD34 & 70 & Yes & Yes & $\begin{array}{l}\text { Mast cells, eosinophils, } \\
\text { neurons, fibrocytes }\end{array}$ & $\begin{array}{l}\text { Regulates cell differentiation, adhesion, trafficking } \\
\text { and proliferation }\end{array}$ & $\begin{array}{l}\text { Quek et al. } 2016 \text { [36] } \\
\text { Engelhardt et al. } 2002 \text { [16] } \\
\text { Nielsen et al. } 2008 \text { [17] }\end{array}$ \\
\hline CD36 & N.D & Yes & No & $\begin{array}{l}\text { Platelets, monocytes, } \\
\text { adipocytes }\end{array}$ & Fatty acid uptake, angiogenesis, PRR recognition & $\begin{array}{l}\text { Silverstein et al. } 2009 \text { [66] } \\
\text { Sachs et al. } 2020 \text { [67] } \\
\text { Herrmann et al. } 2020 \text { [25] }\end{array}$ \\
\hline CD38 & $\begin{array}{c}5-55 \\
\text { (FAB subtypes) }\end{array}$ & Yes & No & $\begin{array}{l}\text { T and B cells, monocytes, } \\
\text { NK, granulocytes, platelets, } \\
\text { red blood cells }\end{array}$ & Regulates calcium levels and NAD+ homeostasis & $\begin{array}{l}\text { Hogan et al. } 2019 \text { [38] } \\
\text { Sarry et al. } 2011[35] \\
\text { Goardon et al. } 2011[40] \\
\text { Keyhani et al. } 2000 \text { [68] }\end{array}$ \\
\hline $\mathrm{CD} 44$ & N.D & Yes & Yes & $\begin{array}{l}\text { T cells, mesenchymal cells, } \\
\text { ectodermal cells, } \\
\text { neuron-like cells }\end{array}$ & Cell adhesion molecule, cellular signaling & $\begin{array}{c}\text { Ponta et al. } 2003[69] \\
\text { Jin et al. } 2006[70] \\
\text { Bendall et al. } 2000[71] \\
\text { Herrmann et al. } 2020[25]\end{array}$ \\
\hline
\end{tabular}


Table 1. Cont

\begin{tabular}{|c|c|c|c|c|c|c|}
\hline Antigen & $\begin{array}{l}\text { Percentage of AML Patients } \\
\text { Expressing the Marker }\end{array}$ & $\begin{array}{l}\text { Expression on } \\
\text { Non-LSC }\end{array}$ & $\begin{array}{l}\text { Expression on } \\
\text { HSC }\end{array}$ & $\begin{array}{c}\text { Expression on Other Healthy } \\
\text { Blood Cells }\end{array}$ & Function in Healthy Conditions & References \\
\hline CD45RA & N.D & Yes & Yes & $\mathrm{T}$ and $\mathrm{B}$ cells & CD45 isoform, cell signaling & $\begin{array}{c}\text { Kersten et al. } 2016 \text { [39] } \\
\text { Goardon et al. } 2011 \text { [40] } \\
\text { Sarry et al. } 2011 \text { [35] } \\
\text { Holmes 2006 [41] }\end{array}$ \\
\hline $\mathrm{CD} 47$ & N.D & Yes & Yes & Various healthy cells & $\begin{array}{l}\text { "don't eat me" signal on cells in order to prevent } \\
\text { inappropriate phagocytosis }\end{array}$ & $\begin{array}{l}\text { Majeti et al. } 2009 \text { [34] } \\
\text { Jaiswal et al. } 2009 \text { [33] } \\
\text { Sick et al. } 2012 \text { [72] }\end{array}$ \\
\hline CD56 & Up to 20 & Yes & No & DC, $T$ and NK cells & Linked to NK cytotoxicity & $\begin{array}{l}\text { Van Acker et al. } 2017 \text { [73] } \\
\text { Sasca et al. } 2019 \text { [74] } \\
\text { Herrmann et al. } 2020[25]\end{array}$ \\
\hline CD69 & N.D & N.D & No & $\mathrm{T}$ cells & $\begin{array}{l}\text { T cell differentiation, tissue retention, } \\
\text { and metabolic reprogramming }\end{array}$ & $\begin{array}{l}\text { Cibrián et al. } 2017 \text { [75] } \\
\text { Sachs et al. } 2020 \text { [67] } \\
\text { Herrmann et al. } 2020 \text { [25] }\end{array}$ \\
\hline CD70 & N.D & Yes & No & DC & $\mathrm{T}$ and $\mathrm{B}$ cell activation & $\begin{array}{c}\text { Riether et al. } 2015 \text { [76] } \\
\text { Riether et al. } 2017 \text { [77] } \\
\text { Borst et al. } 2005 \text { [78] }\end{array}$ \\
\hline CD90 & 40 (in elderly patients) & Yes & Yes & $\begin{array}{l}\text { Fibroblasts, neurons, } \\
\text { endothelial cells }\end{array}$ & Maintenance of HSC, cell adhesion, matrix adhesion & $\begin{array}{c}\text { Buccisano et al. } 2004 \text { [79] } \\
\text { Blair et al. } 1997 \text { [52] } \\
\text { Brendel et al. } 1999 \text { [50] } \\
\text { Kisselbach et al. } 2009 \text { [80] } \\
\text { Craig et al. } 1993 \text { [53] }\end{array}$ \\
\hline CD93 & N.D & N.D & $\begin{array}{l}\text { No (only on } \\
\text { CD34-HSC) }\end{array}$ & Myeloid and endothelial cells & Mechanism in innate host defense & $\begin{array}{l}\text { Bohlson et al. } 2008 \text { [81] } \\
\text { Iwasaki et al. } 2015 \text { [82] } \\
\text { Sumide et al. } 2018 \text { [83] }\end{array}$ \\
\hline CD96 & 27 & Yes & Only $5 \%$ & $\mathrm{~T}$ and NK cells & Inhibits NK and T cells & $\begin{array}{c}\text { Fatlawi et al. } 2016[84] \\
\text { Georgiev et al. } 2018[27] \\
\text { Hosen et al. } 2007 \text { [85] }\end{array}$ \\
\hline CD117 & 87 & Yes & Yes & GMP & Promotes HSC growth by binding the stem cell factor & $\begin{array}{l}\text { Sperling et al. } 1997 \text { [86] } \\
\text { Geissler et al. } 1991 \text { [87] } \\
\text { Quek et al. } 2016 \text { [36] } \\
\text { Wells et al. } 1996 \text { [88] }\end{array}$ \\
\hline CD123 & 97 & Yes & No & Basophils, plasmacytoid DC & $\begin{array}{c}\text { Proliferation, survival, activation, and differentiation } \\
\text { by binding respective ligand }\end{array}$ & $\begin{array}{c}\text { Yu et al. 2016 [88] } \\
\text { Guthridge et al. } 1998 \text { [32] } \\
\text { Bras et al. 2019 [45] } \\
\text { Haubner et al. 2019 [24] } \\
\text { Al-Mawali et al. } 2017 \text { [44] }\end{array}$ \\
\hline CD200 & N.D & Yes & Yes & Myeloid, $\mathrm{T}$ and B cells & Immunoregulatory molecule & $\begin{array}{c}\text { Ngwa et al. } 2019[89] \\
\text { Ho et al. } 2020[90]\end{array}$ \\
\hline
\end{tabular}


Table 1. Cont.

\begin{tabular}{|c|c|c|c|c|c|c|}
\hline Antigen & $\begin{array}{l}\text { Percentage of AML Patients } \\
\text { Expressing the Marker }\end{array}$ & $\begin{array}{l}\text { Expression on } \\
\text { Non-LSC }\end{array}$ & $\begin{array}{l}\text { Expression on } \\
\text { HSC }\end{array}$ & $\begin{array}{c}\text { Expression on Other Healthy } \\
\text { Blood Cells }\end{array}$ & Function in Healthy Conditions & References \\
\hline CD244 & N.D & Yes & Yes & $\begin{array}{l}\text { GMP, HSPC, granulocytes, } \\
\text { monocytes, DC, NK and T cells }\end{array}$ & Regulates NK, T, and DC activation state & $\begin{array}{c}\text { Zhang et al. } 2017 \text { [91] } \\
\text { Haubner et al. } 2019 \text { [24] } \\
\text { Quek et al. } 2016 \text { [36] } \\
\text { Agresta et al. } 2018 \text { [92] }\end{array}$ \\
\hline GPR56 & N.D & No & Yes & Central nervous system, $\mathrm{T}$ cells & $\begin{array}{l}\text { Frontal cortex development, NK inhibition, cell } \\
\text { migration, HSC generation }\end{array}$ & $\begin{array}{c}\text { Pabst et al. } 2016 \text { [93] } \\
\text { Daga et al. } 2019 \text { [55] } \\
\text { Kartalaei et al. } 2015 \text { [94] } \\
\text { Huang et al. } 2018 \text { [95] }\end{array}$ \\
\hline $\begin{array}{l}\text { NKG2DL } \\
\text { (its absence } \\
\text { defines LSC) }\end{array}$ & Highly variable & Yes & No & Not expressed on healthy cells & $\begin{array}{l}\text { Upregulation of NG2DL on malignant or } \\
\text { virus-infected cells resulting in their clearance by } \\
\text { NK cells }\end{array}$ & $\begin{array}{l}\text { Paczulla et al. } 2019 \text { [6] } \\
\text { Zingoni et al. } 2018 \text { [96] }\end{array}$ \\
\hline TIM-3 & 98 & Yes & No & $\begin{array}{l}\text { T cells, monocytes, } \\
\text { macrophages, DC, } \\
\text { and mast cells }\end{array}$ & $\begin{array}{l}\text { Homeostasis-maintaining molecule of the } \\
\text { immune system }\end{array}$ & $\begin{array}{c}\text { Jan et al. } 2011 \text { [97] } \\
\text { Haubner et al. } 2019 \text { [24] } \\
\text { Kikushige et al. } 2010 \text { [98] } \\
\text { Han et al. } 2013 \text { [28] }\end{array}$ \\
\hline
\end{tabular}




\subsubsection{GPR56}

The GPR56 protein was first discovered in neural stem cells, where its mutant form associates with brain malformations [99]. Subsequent studies demonstrated that GPR56 is also expressed on HSC with long-term repopulation potential [94]. Interestingly, GPR56 expression was also detectable on AML cells and specifically on LSC. Pabst and colleagues furthermore observed various level of LSC activity in PDX assays for cells expressing different levels of CD34 and GPR56, with the double positive population showing the highest in vivo leukemia-initiating capacity [93]. Inhibition of GPR56 in leukemic cells decreased BM and tissue infiltration capacity, indicating a functional role in AML LSC. Mechanistically, GPR56 loss was associated with increased leukemic cell apoptosis and impaired ability of LSC to adhere in the BM niche in a RhoA-dependent manner, while colony formation interestingly remained unchanged $[19,100,101]$. Finally, targeting AML cells using a blocking anti-GPR56 antibody demonstrated anti-leukemic activity and prolonged survival in PDX assays [101].

As observed with other LSC markers, high GPR56 expression has been associated with poor clinical outcome in patients [93]. In fact, GPR56 is one of the genes that is part of the 17-genes stemness score [18], and was retrieved as the most strongly expressed gene in NKG2DL- LSC [6]. The involvement of GPR56 in healthy HSC [19] might limit its relevance for AML treatment; however it remains a robust marker for distinguishing LSC from non-LSC.

\subsubsection{CD200}

CD200, a glycoprotein from the immunoglobulin superfamily, represents the latest surface marker described to enrich LSC in both CD34-expressing and non-expressing AML [90]. In healthy blood cells, CD200 was reported to be expressed on HSPCS and other cells (Table 1) and to negatively regulate memory T and NK cells function in AML $[90,102,103]$. In AML cases with $>10 \%$ CD200 ${ }^{+}$among $\mathrm{CD} 45^{\text {dim }}$ cells, leukemic engraftment was only observed from $\mathrm{CD} 200^{+}$cells, while for samples with $<10 \% \mathrm{CD}^{200} 0^{+}$of $\mathrm{CD} 45^{\mathrm{dim}}$ cells, $\mathrm{CD} 200^{+}$cells gave rise to multilineage grafts, indicating contamination with healthy cells [90]. Moreover, CD200 ${ }^{+}$cells encompass both CD $34^{+}$and CD $34^{-}$cells and robustly enrich LSC in PDX assays from CD34 non-expressing NPM1 mutated AML [90]. Finally, transcriptomic data confirmed a HSPC-like signature in $\mathrm{CD}_{200}{ }^{+}$cells when compared to a myeloid-like signature in CD200- cells.

\section{Phenotypic LSC Evolution and Intra-Patient Heterogeneity}

Over the last decade, many studies focused on the phenotypic and molecular characterization of LSC, with the ultimate goal of developing tools for better prediction on disease aggressiveness and improving therapy results by targeting LSC. The field has proven challenging due to the vast heterogeneity between LSC within different AML as well as within one patient during the course of the disease (Figure 2).

Markers like TIM3 [97], CD25 [60], CD32 [60], CD96 [85], and CLL-1 [104] showed LSC enriching abilities in PDX models in some, but not all AML cases. Furthermore, marker expression was noted to sometimes change during the course of the disease even within the same AML. For example, CD25 $5^{+} \mathrm{LSC}$ were shown to give rise to a progeny of CD25- LSC capable of leukemic engraftment in serial transplantation assays in PDX models [61]. CD123 expression was furthermore shown to be highly variable from diagnosis to relapse in AML samples [24,25,45,55]. A possible explanation for phenotypic shifts is genetic evolution, e.g., by acquisition of novel mutations in the same leukemic (sub)clones or partially transformed HSPC (e.g., carrying pre-leukemic mutations) (Figure 2).

This is consistent with the results documented by Becker and colleagues in comparative LSC analyses from paired samples collected from patients at diagnosis or relapse. By using CD34/CD38 or CD32/CD38 gating strategies for CD34 expressing and respectively non-expressing AML, the authors identified differences in LSC phenotype between these two time-points. For example, marker combinations that failed to identify LSC at diagnosis could indeed retrieve subpopulations with LSC activity in the corresponding relapse sample. On the molecular level, these newly engrafting subpopulations isolated 
from the relapse samples gained mutations in i.e., $D N M T 3 A, C D K N 2 A$, and differences highlighted by high-dimensional mass cytometry assays are indicative of molecular evolution [7].

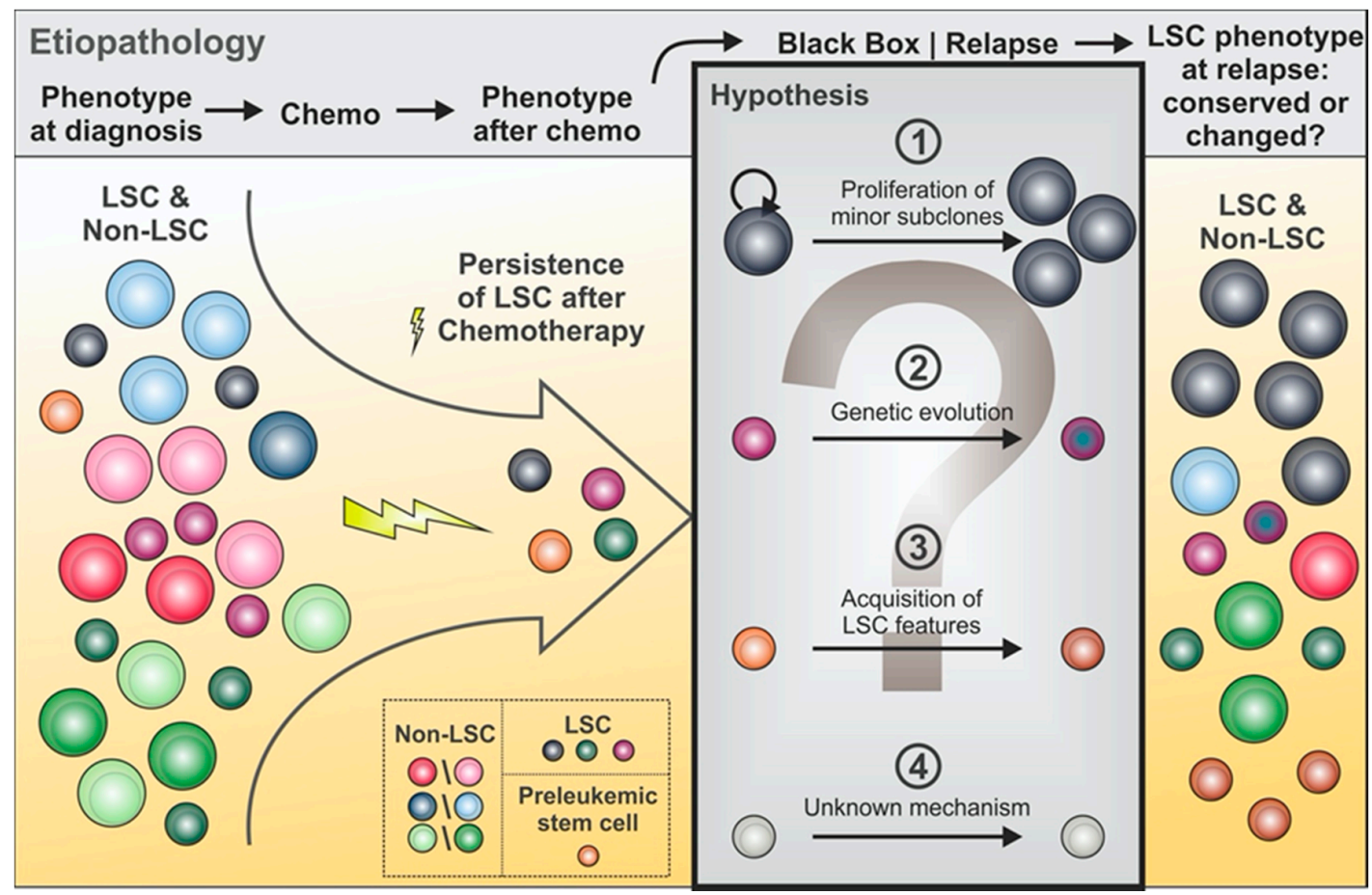

Figure 2. AML evolution and LSC heterogeneity after therapy. At diagnosis, various leukemic (sub)clones with corresponding LSC and non-LSC subpopulations may co-exist next to healthy and pre-malignant HSPC. Sensitivity to treatment varies between such cells, resulting in the elimination of non-LSC and potentially selection of (sub)clones and their corresponding LSC. Relapse may be driven by persistent LSC from the main (sub)clone(s) or from LSC from minor subclones that at diagnosis remained undetectable but then grow out to drive relapse. Furthermore, genetic evolution might occur conferring growth advantages to LSC and perhaps changing their surface phenotype. Finally, new leukemic clones can develop through acquisition of further mutations in the pre-malignant HSPC; disease "relapse" is in this case driven by de novo leukemic clones.

Another major explanation for changes in the LSC phenotype within the same patient is (sub)clonal shifts in response to treatments. As such, initially underrepresented leukemic (sub)clones, which are hypoproliferative and show enhanced therapy resistance, may grow out under therapy, thereby becoming increasingly detectable at later time points. In contrast, less resistant (sub)clones and their LSC compartments may be preferentially eradicated by such therapies. Thus, LSC markers may be conserved or not in diagnosis versus relapse samples, reflecting these shifts in clonal dynamics [25]. Various scenarios have been reported for different AML samples and markers at diagnostic compared to relapse samples (e.g., TIM-3 [24], CLL-1 [55], GPR56: with similar [55] or higher expression [93]), in line with the possibility that relapse-driving therapy-resistant minor clones and their LSC are already present at diagnosis and then survive therapies to cause deadly relapse (Figure 2).

\section{Association between the Genetic Background and the LSC Phenotype in AML}

Several studies have linked genetic alterations with specific phenotypes. As mentioned above, CD34 non-expressing AML often show NPM1 mutations [36,54], while this mutation has also been linked to high expression of CD123 [45]. Furthermore, high CD47 surface expression was associated with FLT3-ITD mutations [34], but not with FLT3-TKD, EVI1 ${ }^{\text {high }}$, NRAS, KRAS, or CEBPA mutations, while TIM3 expression was correlated with core binding factor (CBF)-translocations, $\mathrm{t}(8 ; 21)(\mathrm{q} 22 ; \mathrm{q} 22)$, 
inv(16), or CEBPA [104]. Recently, GMP-like LSC were linked to mutations in CEBPA, DNMT3A, and IDH1 mutations, whereas MPP-like LSC were identified in KRAS and NRAS mutated AML. Finally, lymphoid-primed multipotent progenitor (LMPP)-like LSC were found in AML with TP53 or ASXL1 [105].

AML with a monosomic karyotype, CBF AML, or AML with chromosomal inversion did not show any specific phenotype, but were documented to express CD33 and CD123 at various level like other AML subgroups [63]. CBF-AML commonly associated with low CD33 expression [106], and the specific CBFB MYH11 AML showed enhanced NKG2DL expression [6]. Furthermore, strong expression of CD34 and cKIT were observed in AML with inv(16) [107]. Additionally, the presence of $\mathrm{CD} 34^{+} \mathrm{CD} 123^{+} \mathrm{CD} 25^{+} \mathrm{CD} 99^{+}$subsets has been reported to be associated with FLT3 mutations in NPM1-positive AML [108].

\subsection{GPR56}

GPR56 was identified on LSC of high-risk AML such as EVI1 ${ }^{\text {high }}$ AML [19], but also on LSC from AML with mutations in NPM1 and FLT3 [102], RUNX1 or TP53 [94]. More recently, a higher frequency

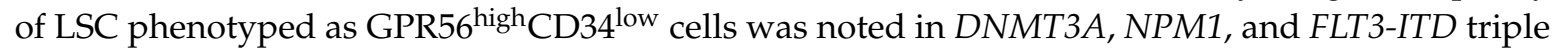
mutated AML, which also showed enrichment for the transcription factor hepatic leukemia factor (HLF) [109]. HLF suppression reduced the LSC content and engraftment ability by slowing cell cycle progression through HES1, a transcriptional repressor, and CDKN1C, a kinase inhibitor that negatively regulates the cell cycle.

\subsection{CD93}

CD93 is a C-type lectin connected to cellular adhesion. Its expression may regulate niche interactions and it was first described as LSC marker in chronic myeloid leukemia [110], but later shown to be also expressed on MLL-rearranged (MLLr) AML [70], specifically on the CD34 ${ }^{+} \mathrm{CD} 38^{-}$compartment. In contrast, healthy cells and leukemic cells from other AML subtypes did not significantly express CD93. When compared to the CD93- ${ }^{-}$counterpart MLLr AML cells, CD93 ${ }^{+}$cells were shown to possess enhanced abilities to induce colonies in colony forming unit assays and leukemia in PDX models. Mechanistically, CD93 expression regulates LSC differentiation, self-renewal capacity, and in vivo progression by modulating the cell cycle inhibitor CDKN2B [71].

\section{3. $C D 26$}

Recently, CD26, a multifunctional ectoenzyme expressed on T cells, was linked to AML bearing FLT3-ITD mutations [25]. The majority of FLT3-ITD positive AML cases also showed higher CD25 levels compared to patients with wild-type FLT3. Interestingly, wild-type FLT3 AML cases did not express CD26 on the surface, but in fact, harbor CD26- ${ }^{-}$LSC. FLT3 ITD positive AML also displayed higher expression of CD33 and CD123 compared to AML LSC with wild-type FLT3 [25], as also documented by other research groups [24,64].

Collectively, genetic backgrounds and respective phenotypes are in parts linked in AML [105] and may be therapeutically exploitable in some cases (e.g., CD93 targeting in MLLr AML [82] or CD26 in FLT3 ITD AML [25]). Specific phenotypes might be the result of mutated genes inducing certain surface markers. Alternatively, phenotypes might reflect the cells of origin with different susceptibility for selected mutations.

\section{Therapeutic Targeting of LSC}

CD33 belongs to the immunoglobulin superfamily and is a member of the sialoadhesin family of cellular interaction molecules. It is expressed on healthy HSPC and myeloid lineage cells [24], with some expression also detectable on peripheral blood lymphocytes and NK cells.

In patients with AML, CD33 is expressed on the majority of leukemic blasts and found on both bulk AML and the LSC $[63,111,112]$. CD33 has been used as a target in AML, alone or in conjunction 
with CD123 [113-115]. Relapse was still observed in these patients, possibly due to escape mechanisms such as absence or downregulation of CD33 expression in LSC [106,116]. Moreover, because of the overlapping expression on healthy cells, targeted therapy against CD33 with the antibody drug conjugate gemtuzumab ozogamicin (GO) showed several adverse events such as hepatotoxicity, cardiotoxicity, hemorrhages, or infections [117-119] and was after first studies withdrawn from clinical use. More recently, GO obtained re-approval for the use in specific clinical applications in patients with AML $[119,120]$.

CD47 is currently also studied as a therapeutical target in AML. Majeti and colleagues initially showed that blockade of the CD47-SIRP $\alpha$ axis using a monoclonal CD47 antibody can induce macrophage-mediated LSC killing and suppress in vivo leukemia development in experimental models [34]. Another in vivo study demonstrated that LSC clearance by macrophage-mediated phagocytosis is dependent on SIRP $\alpha$ signaling [121]. Using a SIRP-Fc fusion protein, the authors showed that disruption of the CD47-SIRP $\alpha$ interaction enhanced phagocytosis, leading to impaired leukemic engraftment of AML cells in NOD/SCID mice. Treatment with a humanized monoclonal antibody against CD47 furthermore eradicated AML LSC, leading to long-term disease-free survival in PDX assays [122]. This antibody has now entered clinical trials in patients with AML and solid tumors. The significance of CD47 as a target in AML therapy was validated in further reports [123,124]. Recent clinical data from another phase $1 \mathrm{~B}$ study indicates that a combination of vincristine and magrolimab, a first-in-class antibody targeting CD47, may be effective in the treatment of AML and MDS [125]. Lately, enhanced CD47 expression was linked to CD123 expression and shown to be responsible for drug resistance in AML that could be overcome by treatment with the histone deacetylase inhibitor Romidepsin [126]. However, phase 1 trials using monoclonal anti-CD47 antibodies were terminated due to insufficient activity (CC-90002, NCT02641002) [127], life threatening side effects (Ti-061, 2016-004372-22; Hu5F9-g4, NCT02678338), or anemia (due to CD47 expression on red blood cells [128]). Results from other currently recruiting clinical trials are underway.

The transmembrane glycoprotein CD44, known to bind hyaluronan, selectins, and osteopontin, displays a plethora of functions in healthy and diseased tissues [69] and has been targeted therapeutically in AML before it was described as an LSC marker. Overall, CD44 shows higher expression in AML cells compared to healthy HSC and displays several splice variants that are heterogeneously distributed among AML cases. High expression of CD44-6v especially correlates with shorter survival in patients with AML [71,129]. Treatment with CD44 antibodies was shown to inhibit proliferation and induce differentiation and apoptosis in AML cells [130-133]. Later on, CD44 targeting was reported to also eradicate AML LSC in PDX assays by impacting LSC trafficking to BM niche [70]. Future research will show whether the therapeutic effect of anti-CD44 antibodies may be potentiated by combinatorial application with other drugs [134].

Targeting CD123 has also been reported to show anti-leukemic effects in preclinical as well as clinical studies. Jin et al., for example, demonstrated that the use of a neutralizing CD123 antibody was able to inhibit leukemogenicity in PDX assays [135]. Ex vivo treatment of bulk AML or LSC with a neutralizing-antibody or direct injection at different time points of this antibody in mice reduced engraftment and improved survival in different animal models. This decrease is linked to a reduced homing combined with an antibody-dependent cell-mediated cytotoxicity (ADCC) effect. On the molecular level, CD123 blockade reduces proliferation and survival of in vitro cultured AML cells [135]. CD123 also helps clinicians to monitor disease outcome, in which CD34+CD38-CD123+ LSC levels are higher in the non-complete remission group [136] and represents an interesting target in cancer treatment (reviewed elsewhere [137]). Clinical trials targeting CD123 were initiated, but unfortunately in several cases, suspended ahead of schedule (i.e., NCT02715011, NCT02113982, or Talacotuzumab, e.g., due to serious adverse events). Interestingly, the single-agent flotetuzumab, an investigational CD123 $\times$ CD3 bispecific DART protein, has shown evidence of clinical activity in a Phase 1 study of relapsed/refractory (R/R) AML $[138,139]$. Further clinical trials using CD123 CAR T cells were initiated (NCT02159495, NCT04230265) with so far promising results [140,141]. 
TIM-3 and CLL-1 are additional surface proteins which make interesting targets, because they are both absent on healthy HSCs (Table 1). Clinical trials with promising results are underway or were performed with agents targeting these molecules (TIM-3, phase $1 \mathrm{~b}$ clinical trial, NCT03066648; CLL-1, [142]).

Finally, the tumor necrosis factor receptor and LSC marker CD70 may also serve as a potential target molecule in AML. Transiently upregulated on immune cells upon activation, CD70 is otherwise not expressed in normal tissues [143]. In AML, CD70 expression was reported to promote blast stemness [77]. Treatment with cusatuzumab, a human $\alpha$ CD70 monoclonal antibody with enhanced antibody-dependent cellular cytotoxicity activity, was recently shown to hold anti-leukemic activity in in vitro and in vivo PDX assays. In a phase 1 study, cusatuzumab alone or in combination with azacitidine showed pronounced efficacy in previously untreated AML patients or patients that are unfit for intensive chemotherapy [144]. Further clinical phase 2 and 3 trials using these approaches are underway.

\section{Concluding Remarks}

LSC and their biology gained great interest in the last decades, since it is now well accepted that efficient targeting of this subpopulation is essential to achieve cure in patients with AML. Defining the surface markers that reliably identify LSC is a critical goal, since it enables further investigations of these subpopulations, monitoring of the clinical course, and the development of novel immunotherapy strategies targeting surface antigens in LSC.

Next to their close molecular relationship to HSPC (Figure 1), the greatest challenge in targeting LSC is their profound heterogeneity among patients as well as within the same patient (see Table 1 'Percentage of AML Patients Expressing the Marker' and Figure 2). The establishment of marker combinations may be required for both diagnostic $[22,24,26,145,146]$ and therapeutic purposes (i.e., targeting CD123/CD47 [126], CD33/TIM3 [24], CLL1/TIM3 [24], CCL1/CD56 [104], or CD33/CD123 [114]). Selected genetic lesions may induce the expression of specific surface antigens (e.g., CD93 on MLL-r AML LSC [82]), which may hold great promise, however, currently remains exceptional and only applicable to rare AML subtypes.

Novel technical developments allowing high-throughput screening of low amounts of cells on both transcriptome [18,25,147], proteome [147,148], and surface antigen level [25] may provide further valuable insights into LSC surface antigens (e.g., identification of the fatty acid translocase CD36 and the type 2 C-lectin receptor CD69 via single-cell RNA sequencing [67]).

Finally, although some surface markers sound appealing as AML targets (e.g., CD123 or CD47), it still remains challenging to safely target them in patients, as observed by many trials still in a lagging phase or stopped due to severe toxicities. Personalized approaches involving multi-antigen detection and validations during disease evolution, or alternative strategies that e.g., induce antigen expression to make LSC targetable for immunological therapies [6] may hold promise for efficient LSC targeting in the future.

Author Contributions: M.A., M.K., C.L., conceptualization; M.A., M.K. and C.L. wrote the manuscript; S.B., figure conceptualization; P.H., M.C., A.M.P.S., P.S.G., manuscript review and critical comments. All authors reviewed and approved the manuscript.

Funding: This research was funded by grants of the Swiss National Foundation (310030_179239 to CL), the Novartis Foundation for Medical-Biological Research to C.L. and the "Stay on Track Program" of the University of Basel to M.K.

Conflicts of Interest: The authors declare no conflict of interest.

\section{References}

1. De Kouchkovsky, I.; Abdul-Hay, M. Acute myeloid leukemia: A comprehensive review and 2016 update. Blood Cancer J. 2016, 6, e441. [CrossRef] [PubMed]

2. Döhner, H.; Weisdorf, D.J.; Bloomfield, C.D. Acute myeloid leukemia. N. Engl. J. Med. 2015, 373, $1136-1152$. [CrossRef] [PubMed] 
3. Lapidot, T.; Sirard, C.; Vormoor, J.; Murdoch, B.; Hoang, T.; Caceres-Cortes, J.; Minden, M.; Paterson, B.; Caligiuri, M.A.; Dick, J.E. A cell initiating human acute myeloid leukaemia after transplantation into SCID mice. Nature 1994, 367, 645-648. [CrossRef] [PubMed]

4. Bonnet, D.; Dick, J.E. Human acute myeloid leukemia is organized as a hierarchy that originates from a primitive hematopoietic cell. Nat. Med. 1997, 3, 730-737. [CrossRef]

5. Bahr, C.; Correia, N.C.; Trumpp, A. Stem cells make leukemia grow again. EMBO J. 2017, 36, 2667-2669. [CrossRef]

6. Paczulla, A.M.; Rothfelder, K.; Raffel, S.; Konantz, M.; Steinbacher, J.; Wang, H.; Tandler, C.; Mbarga, M.; Schaefer, T.; Falcone, M.; et al. Absence of NKG2D ligands defines leukaemia stem cells and mediates their immune evasion. Nature 2019, 572, 254-259. [CrossRef]

7. Ho, T.C.; LaMere, M.; Stevens, B.M.; Ashton, J.M.; Myers, J.R.; O’Dwyer, K.M.; Liesveld, J.L.; Mendler, J.H.; Guzman, M.; Morrissette, J.D.; et al. Evolution of acute myelogenous leukemia stem cell properties after treatment and progression. Blood 2016, 128, 1671-1678. [CrossRef]

8. Pollyea, D.A.; Jordan, C.T. Therapeutic targeting of acute myeloid leukemia stem cells. Blood 2017, 129, 1627-1635. [CrossRef]

9. Wang, X.; Huang, S.; Chen, J.L. Understanding of leukemic stem cells and their clinical implications. Mol. Cancer 2017, 16, 2. [CrossRef]

10. Guilak, F.; Cohen, D.M.; Estes, B.T.; Gimble, J.M.; Liedtke, W.; Chen, C.S. Control of Stem Cell Fate by Physical Interactions with the Extracellular Matrix. Cell Stem Cell 2009, 5, 17-26. [CrossRef]

11. Hoggatt, J.; Kfoury, Y.; Scadden, D.T. Hematopoietic Stem Cell Niche in Health and Disease. Annu. Rev. Pathol. 2016, 11, 555-581. [CrossRef] [PubMed]

12. Sánchez-Aguilera, A.; Méndez-Ferrer, S. The hematopoietic stem-cell niche in health and leukemia. Cell. Mol. Life Sci. 2017, 74, 579-590. [CrossRef] [PubMed]

13. Passegué, E.; Jamieson, C.H.M.; Ailles, L.E.; Weissman, I.L. Normal and leukemic hematopoiesis: Are leukemias a stem cell disorder or a reacquisition of stem cell characteristics? Proc. Natl. Acad. Sci. USA 2003, 100, 11842-11849. [CrossRef] [PubMed]

14. Eppert, K.; Takenaka, K.; Lechman, E.R.; Waldron, L.; Nilsson, B.; van Galen, P.; Metzeler, K.H.; Poeppl, A.; Ling, V.; Beyene, J.; et al. Stem cell gene expression programs influence clinical outcome in human leukemia. Nat. Med. 2011, 17, 1086-1093. [CrossRef] [PubMed]

15. Shlush, L.I.; Zandi, S.; Mitchell, A.; Chen, W.C.; Brandwein, J.M.; Gupta, V.; Kennedy, J.A.; Schimmer, A.D.; Schuh, A.C.; Yee, K.W.; et al. Identification of pre-leukaemic haematopoietic stem cells in acute leukaemia. Nature 2014, 506, 328-333. [CrossRef]

16. Engelhardt, M.; Lübbert, M.; Guo, Y. CD34+ ${ }^{+}$or CD34- ${ }^{-}$Which is the more primitive? Leukemia 2002, 16, $1603-1608$. [CrossRef]

17. Nielsen, J.S.; McNagny, K.M. Erratum: Novel functions of the CD34 family. J. Cell Sci. 2008, 121, 3683-3692. [CrossRef]

18. Ng, S.W.; Mitchell, A.; Kennedy, J.A.; Chen, W.C.; McLeod, J.; Ibrahimova, N.; Arruda, A.; Popescu, A.; Gupta, V.; Schimmer, A.D.; et al. A 17-gene stemness score for rapid determination of risk in acute leukaemia. Nature 2016, 540, 433-437. [CrossRef]

19. Saito, Y.; Morishita, K. Maintenance of leukemic and normal hematopoietic stem cells in bone marrow niches by EVI1-regulated GPR56. Rinsho Ketsueki 2015, 56, 375-383. [CrossRef]

20. Hanekamp, D.; Cloos, J.; Schuurhuis, G.J. Leukemic stem cells: Identification and clinical application. Int. J. Hematol. 2017, 105, 549-557. [CrossRef]

21. Zagozdzon, R.; Golab, J. Cancer stem cells in haematological malignancies. Wspolczesna Onkol. 2015, 19, A1-A6. [CrossRef] [PubMed]

22. Zeijlemaker, W.; Kelder, A.; Cloos, J.; Schuurhuis, G.J. Immunophenotypic Detection of Measurable Residual (Stem Cell) Disease Using LAIP Approach in Acute Myeloid Leukemia. Curr. Protoc. Cytom. 2019, 91, e66. [CrossRef] [PubMed]

23. Zhou, J. Identification and targeting leukemia stem cells: The path to the cure for acute myeloid leukemia. World J. Stem Cells 2014, 6, 473-484. [CrossRef] [PubMed]

24. Haubner, S.; Perna, F.; Köhnke, T.; Schmidt, C.; Berman, S.; Augsberger, C.; Schnorfeil, F.M.; Krupka, C.; Lichtenegger, F.S.; Liu, X.; et al. Coexpression profile of leukemic stem cell markers for combinatorial targeted therapy in AML. Leukemia 2019, 33, 64-74. [CrossRef] [PubMed] 
25. Herrmann, H.; Sadovnik, I.; Eisenwort, G.; Thomas, R.; Blatt, K.; Herndlhofer, S.; Willmann, M.; Stefanzl, G.; Baumgartner, S.; Greiner, G.; et al. Delineation of target expression profiles in $\mathrm{CD}_{3} 4^{+} / \mathrm{CD}^{-} 8^{-}$and $\mathrm{CD}^{+} / \mathrm{CD} 38^{-}$stem and progenitor cells in AML and CML. Blood Adv. 2020, 4, 5118-5132. [CrossRef]

26. Zeijlemaker, W.; Kelder, A.; Oussoren-Brockhoff, Y.J.M.; Scholten, W.J.; Snel, A.N.; Veldhuizen, D.; Cloos, J.; Ossenkoppele, G.J.; Schuurhuis, G.J. A simple one-tube assay for immunophenotypical quantification of leukemic stem cells in acute myeloid leukemia. Leukemia 2016, 30, 439-446. [CrossRef]

27. Georgiev, H.; Ravens, I.; Papadogianni, G.; Bernhardt, G. Coming of age: CD96 emerges as modulator of immune responses. Front. Immunol. 2018, 9, 1072. [CrossRef]

28. Han, G.; Chen, G.; Shen, B.; Li, Y. Tim-3: An activation marker and activation limiter of innate immune cells. Front. Immunol. 2013, 4, 449. [CrossRef]

29. Marshall, A.S.J.; Willment, J.A.; Pyz, E.; Dennehy, K.M.; Reid, D.M.; Dri, P.; Gordon, S.; Wong, S.Y.C.; Brown, G.D. Human MICL (CLEC12A) is differentially glycosylated and is down-regulated following cellular activation. Eur. J. Immunol. 2006, 36, 2159-2169. [CrossRef]

30. Anania, J.C.; Chenoweth, A.M.; Wines, B.D.; MarkHogarth, P. The human Fc $\gamma$ RII (CD32) family of leukocyte FCR in health and disease. Front. Immunol. 2019, 10, 464. [CrossRef]

31. Triplett, T.A.; Curti, B.D.; Bonafede, P.R.; Miller, W.L.; Walker, E.B.; Weinberg, A.D. Defining a functionally distinct subset of human memory CD4+ T cells that are CD25POS and FOXP3NEG. Eur. J. Immunol. 2012, 42, 1893-1905. [CrossRef] [PubMed]

32. Guthridge, M.A.; Stomski, F.C.; Thomas, D.; Woodcock, J.M.; Bagley, C.J.; Berndt, M.C.; Lopez, A.F. Mechanism of activation of the GM-CSF, IL-3, and IL-5 family of receptors. Stem Cells 1998, 16, 301-313. [CrossRef] [PubMed]

33. Jaiswal, S.; Jamieson, C.H.; Pang, W.W.; Park, C.Y.; Chao, M.P.; Majeti, R.; Traver, D.; van Rooijen, N.; Weissman, I.L. CD47 is upregulated on circulating hematopoietic stem cells and leukemia cells to avoid phagocytosis. Cell 2009, 138, 271-285. [CrossRef] [PubMed]

34. Majeti, R.; Chao, M.P.; Alizadeh, A.A.; Pang, W.W.; Jaiswal, S.; Gibbs, K.D.; van Rooijen, N.; Weissman, I.L. CD47 is an adverse prognostic factor and therapeutic antibody target on human acute myeloid leukemia stem cells. Cell 2009, 138, 286-299. [CrossRef] [PubMed]

35. Sarry, J.E.; Murphy, K.; Perry, R.; Sanchez, P.V.; Secreto, A.; Keefer, C.; Swider, C.R.; Strzelecki, A.C.; Cavelier, C.; Recher, C.; et al. Human acute myelogenous leukemia stem cells are rare and heterogeneous when assayed in NOD/SCID/IL2Rgammac-deficient mice. J. Clin. Investig. 2011, 121, 384-395. [CrossRef] [PubMed]

36. Quek, L.; Otto, G.W.; Garnett, C.; Lhermitte, L.; Karamitros, D.; Stoilova, B.; Lau, I.J.; Doondeea, J.; Usukhbayar, B.; Kennedy, A.; et al. Genetically distinct leukemic stem cells in human CD34- acute myeloid leukemia are arrested at a hemopoietic precursor-like stage. J. Exp. Med. 2016, 213, 1513-1535. [CrossRef] [PubMed]

37. Taussig, D.C.; Vargaftig, J.; Miraki-Moud, F.; Griessinger, E.; Sharrock, K.; Luke, T.; Lillington, D.; Oakervee, H.; Cavenagh, J.; Agrawal, S.G.; et al. Leukemia-initiating cells from some acute myeloid leukemia patients with mutated nucleophosmin reside in the CD34- fraction. Blood 2010, 115, 1976-1984. [CrossRef]

38. Hogan, K.A.; Chini, C.C.S.; Chini, E.N. The Multi-faceted Ecto-enzyme CD38: Roles in immunomodulation, cancer, aging, and metabolic diseases. Front. Immunol. 2019, 10, 1187. [CrossRef]

39. Kersten, B.; Valkering, M.; Wouters, R.; van Amerongen, R.; Hanekamp, D.; Kwidama, Z.; Valk, P.; Ossenkoppele, G.; Zeijlemaker, W.; Kaspers, G.; et al. CD45RA, a specific marker for leukaemia stem cell sub-populations in acute myeloid leukaemia. Br. J. Haematol. 2016, 173, 219-235. [CrossRef]

40. Goardon, N.; Marchi, E.; Atzberger, A.; Quek, L.; Schuh, A.; Soneji, S.; Woll, P.; Mead, A.; Alford, K.A.; Rout, R.; et al. Coexistence of LMPP-like and GMP-like leukemia stem cells in acute myeloid leukemia. Cancer Cell 2011, 19, 138-152. [CrossRef]

41. Holmes, N. CD45: All is not yet crystal clear. Immunology 2006, 117, 145-155. [CrossRef] [PubMed]

42. Vergez, F.; Green, A.S.; Tamburini, J.; Sarry, J.E.; Gaillard, B.; Cornillet-Lefebvre, P.; Pannetier, M.; Neyret, A.; Chapuis, N.; Ifrah, N.; et al. High levels of CD34+CD38low/-CD123+ blasts are predictive of an adverse outcome in acute myeloid leukemia: A Groupe Ouest-Est des Leucemies Aigues et Maladies du Sang (GOELAMS) study. Haematologica 2011, 96, 1792-1798. [CrossRef] [PubMed] 
43. Vergez, F.; Nicolau-Travers, M.L.; Bertoli, S.; Rieu, J.B.; Tavitian, S.; Bories, P.; Luquet, I.; Mas, V.; Largeaud, L.; Sarry, A.; et al. CD34 ${ }^{+} \mathrm{CD} 38^{-} \mathrm{CD} 123^{+}$Leukemic Stem Cell Frequency Predicts Outcome in Older Acute Myeloid Leukemia Patients Treated by Intensive Chemotherapy but Not Hypomethylating Agents. Cancers 2020, 12, 1174. [CrossRef] [PubMed]

44. Al-Mawali, A.; Pinto, A.D.; Al-Zadjali, S. CD34+CD38-CD123+ Cells Are Present in Virtually All Acute Myeloid Leukaemia Blasts: A Promising Single Unique Phenotype for Minimal Residual Disease Detection. Acta Haematol. 2017, 138, 175-181. [CrossRef] [PubMed]

45. Bras, A.E.; de Haas, V.; van Stigt, A.; Jongen-Lavrencic, M.; Beverloo, H.B.; te Marvelde, J.G.; Zwaan, C.M.; van Dongen, J.J.M.; Leusen, J.H.W.; van der Velden, V.H.J. CD123 expression levels in 846 acute leukemia patients based on standardized immunophenotyping. Cytom. Part B Clin. Cytom. 2019, 96, 134-142. [CrossRef] [PubMed]

46. Paprocka, M.; Bielawska-Pohl, A.; Rossowska, J.; Krawczenko, A.; Duś, D.; Kiełbiński, M.; Haus, O.; Podolak-Dawidziak, M.; Kuliczkowski, K. MRP1 protein expression in leukemic stem cells as a negative prognostic marker in acute myeloid leukemia patients. Eur. J. Haematol. 2017, 99, 415-422. [CrossRef] [PubMed]

47. Touzet, L.; Dumezy, F.; Roumier, C.; Berthon, C.; Bories, C.; Quesnel, B.; Preudhomme, C.; Boyer, T. CD9 in acute myeloid leukemia: Prognostic role and usefulness to target leukemic stem cells. Cancer Med. 2019, 8, 1279-1288. [CrossRef]

48. Huang, C.L.; Taki, T.; Adachi, M.; Yagita, M.; Sawada, S.; Takabayashi, A.; Inufusa, H.; Yoshie, O.; Miyake, M. MRP-1/CD9 and KAI1/CD82 expression in normal and various cancer tissues. Int. J. Oncol. 1997, 11, 1045-1051. [CrossRef]

49. Wang, V.M.Y.; Ferreira, R.M.M.; Almagro, J.; Evan, T.; Legrave, N.; Thin, M.Z.; Frith, D.; Carvalho, J.; Barry, D.J.; Snijders, A.P.; et al. CD9 identifies pancreatic cancer stem cells and modulates glutamine metabolism to fuel tumour growth. Nat. Cell Biol. 2019, 21, 1425-1435. [CrossRef]

50. Brendel, C.; Mohr, B.; Schimmelpfennig, C.; Muller, J.; Bornhauser, M.; Schmidt, M.; Ritter, M.; Ehninger, G.; Neubauer, A. Detection of cytogenetic aberrations both in CD90 (Thy-1)-positive and (Thy-1)-negative stem cell (CD34) subfractions of patients with acute and chronic myeloid leukemias. Leukemia 1999, 13, 1770-1775. [CrossRef]

51. Miyamoto, T.; Weissman, I.L.; Akashi, K. AML1/ETO-expressing nonleukemic stem cells in acute myelogenous leukemia with 8;21 chromosomal translocation. Proc. Natl. Acad. Sci. USA 2000, 97, 7521-7526. [CrossRef] [PubMed]

52. Blair, A.; Hogge, D.E.; Ailles, L.E.; Lansdorp, P.M.; Sutherland, H.J. Lack of expression of Thy-1 (CD90) on acute myeloid leukemia cells with long-term proliferative ability in vitro and in vivo. Blood 1997, 89, 3104-3112. [CrossRef] [PubMed]

53. Craig, W.; Kay, R.; Cutler, R.L.; Lansdorp, P.M. Expression of Thy-1 on human hematopoietic progenitor cells. J. Exp. Med. 1993, 177, 1331-1342. [CrossRef] [PubMed]

54. Falini, B.; Nicoletti, I.; Martelli, M.F.; Mecucci, C. Acute myeloid leukemia carrying cytoplasmic/mutated nucleophosmin (NPMc ${ }^{+}$AML): Biologic and clinical features. Blood 2007, 109, 874-885. [CrossRef]

55. Daga, S.; Rosenberger, A.; Quehenberger, F.; Krisper, N.; Prietl, B.; Reinisch, A.; Zebisch, A.; Sill, H.; Wolfler, A. High GPR56 surface expression correlates with a leukemic stem cell gene signature in CD34-positive AML. Cancer Med. 2019, 8, 1771-1778. [CrossRef]

56. Larsen, H.O.; Roug, A.S.; Just, T.; Brown, G.D.; Hokland, P. Expression of the hMICL in acute myeloid leukemia-a highly reliable disease marker at diagnosis and during follow-up. Cytom. B Clin. Cytom. 2012, 82, 3-8. [CrossRef]

57. Bakker, A.B.; van den Oudenrijn, S.; Bakker, A.Q.; Feller, N.; van Meijer, M.; Bia, J.A.; Jongeneelen, M.A.; Visser, T.J.; Bijl, N.; Geuijen, C.A.; et al. C-type lectin-like molecule-1: A novel myeloid cell surface marker associated with acute myeloid leukemia. Cancer Res. 2004, 64, 8443-8450. [CrossRef]

58. Jiang, Y.P.; Liu, B.Y.; Zheng, Q.; Panuganti, S.; Chen, R.; Zhu, J.; Mishra, M.; Huang, J.; Dao-Pick, T.; Roy, S.; et al. CLT030, a leukemic stem cell-targeting CLL1 antibody-drug conjugate for treatment of acute myeloid leukemia. Blood Adv. 2018, 2, 1738-1749. [CrossRef]

59. Brosseau, C.; Colas, L.; Magnan, A.; Brouard, S. CD9 tetraspanin: A new pathway for the regulation of inflammation? Front. Immunol. 2018, 9, 2316. [CrossRef] 
60. Saito, Y.; Kitamura, H.; Hijikata, A.; Tomizawa-Murasawa, M.; Tanaka, S.; Takagi, S.; Uchida, N.; Suzuki, N.; Sone, A.; Najima, Y.; et al. Identification of therapeutic targets for quiescent, chemotherapy-resistant human leukemia stem cells. Sci. Transl. Med. 2010, 2, 17ra19. [CrossRef]

61. Kageyama, Y.; Miwa, H.; Arakawa, R.; Tawara, I.; Ohishi, K.; Masuya, M.; Nakase, K.; Katayama, N. Expression of CD25 fluctuates in the leukemia-initiating cell population of CD25-positive AML. PLoS ONE 2018, 13, e0209295. [CrossRef] [PubMed]

62. Klemann, C.; Wagner, L.; Stephan, M.; von Hörsten, S. Cut to the chase: A review of CD26/dipeptidyl peptidase-4's (DPP4) entanglement in the immune system. Clin. Exp. Immunol. 2016, 185, 1-21. [CrossRef] [PubMed]

63. Ehninger, A.; Kramer, M.; Röllig, C.; Thiede, C.; Bornhäuser, M.; von Bonin, M.; Wermke, M.; Feldmann, A.; Bachmann, M.; Ehninger, G.; et al. Distribution and levels of cell surface expression of CD33 and CD123 in acute myeloid leukemia. Blood Cancer J. 2014, 4, e218. [CrossRef] [PubMed]

64. Liu, X.-L.; Yuan, J.-Y.; Zhang, J.-W.; Zhang, X.-H.; Wang, R.-X. Differential gene expression in human hematopoietic stem cells specified toward erythroid, megakaryocytic, and granulocytic lineage. J. Leukoc. Biol. 2007, 82, 986-1002. [CrossRef] [PubMed]

65. Laszlo, G.S.; Estey, E.H.; Walter, R.B. The past and future of CD33 as therapeutic target in acute myeloid leukemia. Blood Rev. 2014, 28, 143-153. [CrossRef]

66. Silverstein, R.L.; Febbraio, M. CD36, a scavenger receptor involved in immunity, metabolism, angiogenesis, and behavior. Sci. Signal. 2009, 2, re3. [CrossRef]

67. Sachs, K.; Sarver, A.L.; Noble-Orcutt, K.E.; LaRue, R.S.; Antony, M.L.; Chang, D.; Lee, Y.; Navis, C.M.; Hillesheim, A.L.; Nykaza, I.R.; et al. Single-cell gene expression analyses reveal distinct self-renewing and proliferating subsets in the leukemia stem cell compartment in acute myeloid leukemia. Cancer Res. 2020, 80, 458-470. [CrossRef]

68. Keyhani, A.; Huh, Y.O.; Jendiroba, D.; Pagliaro, L.; Cortez, J.; Pierce, S.; Pearlman, M.; Estey, E.; Kantarjian, H.; Freireich, E.J. Increased CD38 expression is associated with favorable prognosis in adult acute leukemia. Leuk. Res. 2000, 24, 153-159. [CrossRef]

69. Ponta, H.; Sherman, L.; Herrlich, P.A. CD44: From adhesion molecules to signalling regulators. Nat. Rev. Mol. Cell Biol. 2003, 4, 33-45. [CrossRef]

70. Jin, L.; Hope, K.J.; Zhai, Q.; Smadja-Joffe, F.; Dick, J.E. Targeting of CD44 eradicates human acute myeloid leukemic stem cells. Nat. Med. 2006, 12, 1167-1174. [CrossRef]

71. Bendall, L.J.; Bradstock, K.F.; Gottlieb, D.J. Expression of CD44 variant exons in acute myeloid leukemia is more common and more complex than that observed in normal blood, bone marrow or CD34+ cells. Leukemia 2000, 14, 1239-1246. [CrossRef] [PubMed]

72. Sick, E.; Jeanne, A.; Schneider, C.; Dedieu, S.; Takeda, K.; Martiny, L. CD47 update: A multifaceted actor in the tumour microenvironment of potential therapeutic interest. Br. J. Pharmacol. 2012, 167, 1415-1430. [CrossRef] [PubMed]

73. Van Acker, H.H.; Capsomidis, A.; Smits, E.L.; Van Tendeloo, V.F. CD56 in the immune system: More than a marker for cytotoxicity? Front. Immunol. 2017, 8, 892. [CrossRef] [PubMed]

74. Sasca, D.; Szybinski, J.; Schüler, A.; Shah, V.; Heidelberger, J.; Haehnel, P.S.; Dolnik, A.; Kriege, O.; Fehr, E.M.; Gebhardt, W.H.; et al. NCAM1 (CD56) promotes leukemogenesis and confers drug resistance in AML. Blood 2019, 133, 2305-2319. [CrossRef]

75. Cibrián, D.; Sánchez-Madrid, F. CD69: From activation marker to metabolic gatekeeper. Eur. J. Immunol. 2017, 47, 946-953. [CrossRef]

76. Riether, C.; Schürch, C.M.; Ochsenbein, A.F. Regulation of hematopoietic and leukemic stem cells by the immune system. Cell Death Differ. 2015, 22, 187-198. [CrossRef]

77. Riether, C.; Schürch, C.M.; Bührer, E.D.; Hinterbrandner, M.; Huguenin, A.L.; Hoepner, S.; Zlobec, I.; Pabst, T.; Radpour, R.; Ochsenbein, A.F. CD70/CD27 signaling promotes blast stemness and is a viable therapeutic target in acute myeloid leukemia. J. Exp. Med. 2017, 214, 359-380. [CrossRef]

78. Borst, J.; Hendriks, J.; Xiao, Y. CD27 and CD70 in T cell and B cell activation. Curr. Opin. Immunol. 2005, 17, $275-281$. [CrossRef]

79. Buccisano, F.; Rossi, F.M.; Venditti, A.; Del Poeta, G.; Cox, M.C.; Abbruzzese, E.; Rupolo, M.; Berretta, M.; Degan, M.; Russo, S.; et al. CD90/Thy-1 is preferentially expressed on blast cells of high risk acute myeloid leukaemias. Br. J. Haematol. 2004, 125, 203-212. [CrossRef] 
80. Kisselbach, L.; Merges, M.; Bossie, A.; Boyd, A. CD90 expression on human primary cells and elimination of contaminating fibroblasts from cell cultures. Cytotechnology 2009, 59, 31-44. [CrossRef]

81. Bohlson, S.; Greenlee, M.; Sullivan, S. CD93 and Related Family Members: Their Role in Innate Immunity. Curr. Drug Targets 2008, 9, 130-138. [CrossRef] [PubMed]

82. Iwasaki, M.; Liedtke, M.; Gentles, A.J.; Cleary, M.L. CD93 marks a non-quiescent human leukemia stem cell population and is required for development of MLL-rearranged acute myeloid leukemia. Cell Stem Cell 2015, 17, 412-421. [CrossRef] [PubMed]

83. Sumide, K.; Matsuoka, Y.; Kawamura, H.; Nakatsuka, R.; Fujioka, T.; Asano, H.; Takihara, Y.; Sonoda, Y. A revised road map for the commitment of human cord blood CD34-negative hematopoietic stem cells. Nat. Commun. 2018, 9, 2202. [CrossRef] [PubMed]

84. Al-Fatlawi, H.; Musa, R. Evaluation of CD96 and CD123 in CD34+ leukemic stem cells in acute myeloid leukemia patients and their relation to response to induction therapy. Iraqi J. Hematol. 2016, 5, 161-166. [CrossRef]

85. Hosen, N.; Park, C.Y.; Tatsumi, N.; Oji, Y.; Sugiyama, H.; Gramatzki, M.; Krensky, A.M.; Weissman, I.L. CD96 is a leukemic stem cell-specific marker in human acute myeloid leukemia. Proc. Natl. Acad. Sci. USA 2007, 104, 11008-11013. [CrossRef]

86. Sperling, C.; Schwartz, S.; Büchner, T.; Thiel, E.; Ludwig, W.D. Expression of the stem cell factor receptor C-KIT (CD117) in acute leukemias. Haematologica 1997, 82, 617-621.

87. Geissler, E.N.; Liao, M.; Brook, J.D.; Martin, F.H.; Zsebo, K.M.; Housman, D.E.; Galli, S.J. Stem cell factor (SCF), a novel hematopoietic growth factor and ligand for c-kit tyrosine kinase receptor, maps on human chromosome 12 between 12q14.3 and 12qter. Somat Cell Mol. Genet. 1991, 17, 207-214. [CrossRef]

88. Wells, S.J.; Bray, R.A.; Stempora, L.L.; Farhi, D.C. CD117/CD34 expression in leukemic blasts. Am. J. Clin. Pathol. 1996, 106, 192-195. [CrossRef]

89. Ngwa, C.; Liu, F. CD200-CD200R signaling and diseases: A potential therapeutic target? Int. J. Physiol. Pathophysiol. Pharmcol. 2019, 11, 297-309.

90. Ho, J.M.; Dobson, S.M.; Voisin, V.; McLeod, J.; Kennedy, J.A.; Mitchell, A.; Jin, L.; Eppert, K.; Bader, G.; Minden, M.D.; et al. CD200 expression marks leukemia stem cells in human AML. Blood Adv. 2020, 4, 5402-5413. [CrossRef]

91. Zhang, F.; Liu, X.; Chen, C.; Zhu, J.; Yu, Z.; Xie, J.; Xie, L.; Bai, H.; Zhang, Y.; Fang, X.; et al. CD244 maintains the proliferation ability of leukemia initiating cells through SHP-2/p27kip1 signaling. Haematologica 2017, 102, 707-718. [CrossRef] [PubMed]

92. Agresta, L.; Hoebe, K.H.N.; Janssen, E.M. The emerging role of CD244 signaling in immune cells of the tumor microenvironment. Front. Immunol. 2018, 9, 2809. [CrossRef] [PubMed]

93. Pabst, C.; Bergeron, A.; Lavallée, V.P.; Yeh, J.; Gendron, P.; Norddahl, G.L.; Krosl, J.; Boivin, I.; Deneault, E.; Simard, J.; et al. GPR56 identifies primary human acute myeloid leukemia cells with high repopulating potential in vivo. Blood 2016, 127, 2018-2027. [CrossRef] [PubMed]

94. Solaimani Kartalaei, P.; Yamada-Inagawa, T.; Vink, C.S.; de Pater, E.; van der Linden, R.; Marks-Bluth, J.; van der Sloot, A.; van den Hout, M.; Yokomizo, T.; van Schaick-Solerno, M.L.; et al. Whole-transcriptome analysis of endothelial to hematopoietic stem cell transition reveals a requirement for Gpr56 in HSC generation. J. Exp. Med. 2015, 212, 93-106. [CrossRef]

95. Huang, K.Y.; Lin, H.H. The activation and signaling mechanisms of GPR56/ADGRG1 in melanoma cell. Front. Oncol. 2018, 8, 304. [CrossRef]

96. Zingoni, A.; Molfetta, R.; Fionda, C.; Soriani, A.; Paolini, R.; Cippitelli, M.; Cerboni, C.; Santoni, A. NKG2D and its ligands: "One for all, all for one". Front. Immunol. 2018, 9, 476. [CrossRef]

97. Jan, M.; Chao, M.P.; Cha, A.C.; Alizadeh, A.A.; Gentles, A.J.; Weissman, I.L.; Majeti, R. Prospective separation of normal and leukemic stem cells based on differential expression of TIM3, a human acute myeloid leukemia stem cell marker. Proc. Natl. Acad. Sci. USA 2011, 108, 5009-5014. [CrossRef]

98. Kikushige, Y.; Shima, T.; Takayanagi, S.; Urata, S.; Miyamoto, T.; Iwasaki, H.; Takenaka, K.; Teshima, T.; Tanaka, T.; Inagaki, Y.; et al. TIM-3 is a promising target to selectively kill acute myeloid leukemia stem cells. Cell Stem Cell 2010, 7, 708-717. [CrossRef]

99. Piao, X.; Hill, R.S.; Bodell, A.; Chang, B.S.; Basel-Vanagaite, L.; Straussberg, R.; Dobyns, W.B.; Qasrawi, B.; Winter, R.M.; Innes, A.M.; et al. G protein-coupled receptor-dependent development of human frontal cortex. Science 2004, 303, 2033-2036. [CrossRef] 
100. Saha, H.R.; Kaneda-Nakashima, K.; Shimosaki, S.; Suekane, A.; Sarkar, B.; Saito, Y.; Ogoh, H.; Nakahata, S.; Inoue, K.; Watanabe, T.; et al. Suppression of GPR56 expression by pyrrole-imidazole polyamide represents a novel therapeutic drug for AML with high EVI1 expression. Sci. Rep. 2018, 8, 13741. [CrossRef]

101. Daria, D.; Kirsten, N.; Muranyi, A.; Mulaw, M.; Thme, S.; Kechter, A.; Hollnagel, M.; Bullinger, L.; Döhner, K.; Döhner, H.; et al. GPR56 contributes to the development of acute myeloid leukemia in mice. Leukemia 2016, 30, 1734-1741. [CrossRef] [PubMed]

102. Coles, S.J.; Hills, R.K.; Wang, E.C.; Burnett, A.K.; Man, S.; Darley, R.L.; Tonks, A. Expression of CD200 on AML blasts directly suppresses memory T-cell function. Leukemia 2012, 26, 2148-2151. [CrossRef] [PubMed]

103. Coles, S.J.; Wang, E.C.; Man, S.; Hills, R.K.; Burnett, A.K.; Tonks, A.; Darley, R.L. CD200 expression suppresses natural killer cell function and directly inhibits patient anti-tumor response in acute myeloid leukemia. Leukemia 2011, 25, 792-799. [CrossRef] [PubMed]

104. Van Rhenen, A.; van Dongen, G.A.; Kelder, A.; Rombouts, E.J.; Feller, N.; Moshaver, B.; Stigter-van Walsum, M.; Zweegman, S.; Ossenkoppele, G.J.; Jan Schuurhuis, G. The novel AML stem cell associated antigen CLL-1 aids in discrimination between normal and leukemic stem cells. Blood 2007, 110, 2659-2666. [CrossRef] [PubMed]

105. Han, H.; Byun, J.M.; Shin, D.Y.; Yoon, S.S.; Koh, Y.; Hong, J.; Kim, I.; Lee, C.; Yoo, H.; Yun, H.; et al. Leukemic stem cell phenotype is associated with mutational profile in acute myeloid leukemia. Korean J. Intern. Med. 2020. [CrossRef]

106. Khan, N.; Hills, R.K.; Virgo, P.; Couzens, S.; Clark, N.; Gilkes, A.; Richardson, P.; Knapper, S.; Grimwade, D.; Russell, N.H.; et al. Expression of CD33 is a predictive factor for effect of gemtuzumab ozogamicin at different doses in adult acute myeloid leukaemia. Leukemia 2017, 31, 1059-1068. [CrossRef]

107. Béné, M.-C.; Porwit, A. Examples of Immunophenotypic Features in Various Categories of Acute Leukaemia. In Multiparameter Flow Cytometry in the Diagnosis of Hematologic Malignancies; Porwit, A., Béné, M.C., Eds.; Cambridge University Press: Cambridge, UK, 2018; pp. 75-88.

108. Angelini, D.F.; Ottone, T.; Guerrera, G.; Lavorgna, S.; Cittadini, M.; Buccisano, F.; De Bardi, M.; Gargano, F.; Maurillo, L.; Divona, M.; et al. A Leukemia-Associated CD34/CD123/CD25/CD99+ Immunophenotype Identifies FLT3-Mutated Clones in Acute Myeloid Leukemia. Clin. Cancer Res. 2015, 21,3977-3985. [CrossRef]

109. Garg, S.; Reyes-Palomares, A.; He, L.; Bergeron, A.; Lavallée, V.P.; Lemieux, S.; Gendron, P.; Rohde, C.; Xia, J.; Jagdhane, P.; et al. Hepatic leukemia factor is a novel leukemic stem cell regulator in DNMT3A, NPM1, and FLT3-ITD triple-mutated AML. Blood 2019, 134, 263-276. [CrossRef]

110. Kinstrie, R.; Horne, G.A.; Morrison, H.; Irvine, D.; Munje, C.; Castañeda, E.G.; Moka, H.A.; Dunn, K.; Cassels, J.E.; Parry, N.; et al. CD93 is expressed on chronic myeloid leukemia stem cells and identifies a quiescent population which persists after tyrosine kinase inhibitor therapy. Leukemia 2020, 34, 1613-1625. [CrossRef]

111. Taussig, D.C.; Pearce, D.J.; Simpson, C.; Rohatiner, A.Z.; Lister, T.A.; Kelly, G.; Luongo, J.L.; Danet-Desnoyers, G.A.; Bonnet, D. Hematopoietic stem cells express multiple myeloid markers: Implications for the origin and targeted therapy of acute myeloid leukemia. Blood 2005, 106, 4086-4092. [CrossRef]

112. Hauswirth, A.W.; Florian, S.; Printz, D.; Sotlar, K.; Krauth, M.T.; Fritsch, G.; Schernthaner, G.H.; Wacheck, V.; Selzer, E.; Sperr, W.R.; et al. Expression of the target receptor CD33 in CD34+/CD38-/CD123+ AML stem cells. Eur. J. Clin. Investig. 2007, 37, 73-82. [CrossRef] [PubMed]

113. Kügler, M.; Stein, C.; Kellner, C.; Mentz, K.; Saul, D.; Schwenkert, M.; Schubert, I.; Singer, H.; Oduncu, F.; Stockmeyer, B.; et al. A recombinant trispecific single-chain Fv derivative directed against CD123 and CD33 mediates effective elimination of acute myeloid leukaemia cells by dual targeting. Br. J. Haematol. 2010, 150, 574-586. [CrossRef] [PubMed]

114. Pizzitola, I.; Anjos-Afonso, F.; Rouault-Pierre, K.; Lassailly, F.; Tettamanti, S.; Spinelli, O.; Biondi, A.; Biagi, E.; Bonnet, D. Chimeric antigen receptors against CD33/CD123 antigens efficiently target primary acute myeloid leukemia cells in vivo. Leukemia 2014, 28, 1596-1605. [CrossRef] [PubMed]

115. Larson, R.A.; Sievers, E.L.; Stadtmauer, E.A.; Löwenberg, B.; Estey, E.H.; Dombret, H.; Theobald, M.; Voliotis, D.; Bennett, J.M.; Richte, M.; et al. Final report of the efficacy and safety of gemtuzumab ozogamicin (Mylotarg) in patients with CD33-positive acute myeloid leukemia in first recurrence. Cancer 2005, 104, 1442-1452. [CrossRef] [PubMed] 
116. Jawad, M.; Seedhouse, C.; Mony, U.; Grundy, M.; Russell, N.H.; Pallis, M. Analysis of factors that affect in vitro chemosensitivity of leukaemic stem and progenitor cells to gemtuzumab ozogamicin (Mylotarg) in acute myeloid leukaemia. Leukemia 2010, 24, 74-80. [CrossRef] [PubMed]

117. Giles, F.J.; Kantarjian, H.M.; Kornblau, S.M.; Thomas, D.A.; Garcia-Manero, G.; Waddelow, T.A.; David, C.L.; Phan, A.T.; Colburn, D.E.; Rashid, A.; et al. Mylotarg (gemtuzumab ozogamicin) therapy is associated with hepatic venoocclusive disease in patients who have not received stem cell transplantation. Cancer 2001, 92, 406-413. [CrossRef]

118. Bross, P.F.; Beitz, J.; Chen, G.; Chen, X.H.; Duffy, E.; Kieffer, L.; Roy, S.; Sridhara, R.; Rahman, A.; Williams, G.; et al. Approval summary: Gemtuzumab ozogamicin in relapsed acute myeloid leukemia. Clin. Cancer Res. 2001, 7, 1490-1496.

119. Selby, C.; Yacko, L.R.; Glode, A.E. Gemtuzumab Ozogamicin: Back Again. J. Adv. Pract. Oncol. 2019, 10, 68-82.

120. Egan, P.C.; Reagan, J.L. The return of gemtuzumab ozogamicin: A humanized anti-CD33 monoclonal antibody-drug conjugate for the treatment of newly diagnosed acute myeloid leukemia. OncoTargets Ther. 2018, 11, 8265-8272. [CrossRef]

121. Theocharides, A.P.; Jin, L.; Cheng, P.Y.; Prasolava, T.K.; Malko, A.V.; Ho, J.M.; Poeppl, A.G.; van Rooijen, N.; Minden, M.D.; Danska, J.S.; et al. Disruption of SIRPalpha signaling in macrophages eliminates human acute myeloid leukemia stem cells in xenografts. J. Exp. Med. 2012, 209, 1883-1899. [CrossRef]

122. Liu, J.; Wang, L.; Zhao, F.; Tseng, S.; Narayanan, C.; Shura, L.; Willingham, S.; Howard, M.; Prohaska, S.; Volkmer, J.; et al. Pre-Clinical Development of a Humanized Anti-CD47 Antibody with Anti-Cancer Therapeutic Potential. PLoS ONE 2015, 10, e0137345. [CrossRef] [PubMed]

123. Ponce, L.P.; Fenn, N.C.; Moritz, N.; Krupka, C.; Kozik, J.H.; Lauber, K.; Subklewe, M.; Hopfner, K.P. SIRPalpha-antibody fusion proteins stimulate phagocytosis and promote elimination of acute myeloid leukemia cells. Oncotarget 2017, 8, 11284-11301. [CrossRef] [PubMed]

124. Petrova, P.S.; Viller, N.N.; Wong, M.; Pang, X.; Lin, G.H.; Dodge, K.; Chai, V.; Chen, H.; Lee, V.; House, V.; et al. TTI-621 (SIRPalphaFc): A CD47-Blocking Innate Immune Checkpoint Inhibitor with Broad Antitumor Activity and Minimal Erythrocyte Binding. Clin. Cancer Res. 2017, 23, 1068-1079. [CrossRef] [PubMed]

125. Sallman, D.A.; Asch, A.S.; Al Malki, M.M.; Lee, D.J.; Donnellan, W.B.; Marcucci, G.; Kambhampati, S.; Daver, N.G.; Garcia-Manero, G.; Komrokji, R.S.; et al. The First-in-Class Anti-CD47 Antibody Magrolimab (5F9) in Combination with Azacitidine Is Effective in MDS and AML Patients: Ongoing Phase 1b Results. Blood 2019, 134 (Suppl. 1), 569. [CrossRef]

126. Yan, B.; Chen, Q.; Shimada, K.; Tang, M.; Li, H.; Gurumurthy, A.; Khoury, J.D.; Xu, B.; Huang, S.; Qiu, Y. Histone deacetylase inhibitor targets CD123/CD47-positive cells and reverse chemoresistance phenotype in acute myeloid leukemia. Leukemia 2019, 33, 931-944. [CrossRef] [PubMed]

127. Eladl, E.; Tremblay-LeMay, R.; Rastgoo, N.; Musani, R.; Chen, W.; Liu, A.; Chang, H. Role of CD47 in Hematological Malignancies. J. Hematol. Oncol. 2020, 13, 96. [CrossRef] [PubMed]

128. Brierley, C.K.; Staves, J.; Roberts, C.; Johnson, H.; Vyas, P.; Goodnough, L.T.; Murphy, M.F. The effects of monoclonal anti-CD47 on RBCs, compatibility testing, and transfusion requirements in refractory acute myeloid leukemia. Transfusion 2019, 59, 2248-2254. [CrossRef] [PubMed]

129. Stauder, R.; Curt, F.; Oliferenko, S.; Marie, J.P.; Proctor, S.; Jasmin, C. A strong expression of CD44-6v correlates with shorter survival of patients with acute myeloid leukemia. Blood 1998, 91, 3401-3413.

130. Charrad, R.S.; Li, Y.; Delpech, B.; Balitrand, N.; Clay, D.; Jasmin, C.; Chomienne, C.; Smadja-Joffe, F. Ligation of the CD44 adhesion molecule reverses blockage of differentiation in human acute myeloid leukemia. Nat. Med. 1999, 5, 669-676. [CrossRef]

131. Charrad, R.S.; Gadhoum, Z.; Qi, J.; Glachant, A.; Allouche, M.; Jasmin, C.; Chomienne, C.; Smadja-Joffe, F. Effects of anti-CD44 monoclonal antibodies on differentiation and apoptosis of human myeloid leukemia cell lines. Blood 2002, 99, 290-299. [CrossRef]

132. Gadhoum, Z.; Leibovitch, M.P.; Oi, J.; Dumenil, D.; Durand, L.; Leibovitch, S.; Smadja-Joffe, F. CD44: A new means to inhibit acute myeloid leukemia cell proliferation via p27Kip1. Blood 2004, 103, 1059-1068. [CrossRef] [PubMed]

133. Song, G.; Liao, X.; Zhou, L.; Wu, L.; Feng, Y.; Han, Z.C. HI44a, an anti-CD44 monoclonal antibody, induces differentiation and apoptosis of human acute myeloid leukemia cells. Leuk. Res. 2004, 28, 1089-1096. [CrossRef] [PubMed] 
134. Vey, N.; Delaunay, J.; Martinelli, G.; Fiedler, W.; Raffoux, E.; Prebet, T.; Gomez-Roca, C.; Papayannidis, C.; Kebenko, M.; Paschka, P.; et al. Phase I clinical study of RG7356, an anti-CD44 humanized antibody, in patients with acute myeloid leukemia. Oncotarget 2016, 7, 32532-32542. [CrossRef] [PubMed]

135. Jin, L.; Lee, E.M.; Ramshaw, H.S.; Busfield, S.J.; Peoppl, A.G.; Wilkinson, L.; Guthridge, M.A.; Thomas, D.; Barry, E.F.; Boyd, A.; et al. Monoclonal antibody-mediated targeting of CD123, IL-3 receptor alpha chain, eliminates human acute myeloid leukemic stem cells. Cell Stem Cell 2009, 5, 31-42. [CrossRef] [PubMed]

136. Zahran, A.M.; Aly, S.S.; Rayan, A.; El-Badawy, O.; Fattah, M.A.; Ali, A.M.; ElBadre, H.M.; Hetta, H.F. Survival outcomes of CD34+CD38-LSCs and their expression of CD123 in adult AML patients. Oncotarget 2018, 9, 34056-34065. [CrossRef]

137. Testa, U.; Pelosi, E.; Castelli, G. CD123 as a therapeutic target in the treatment of hematological malignancies. Cancers 2019, 11, 1358. [CrossRef]

138. Uy, G.L.; Aldoss, I.; Foster, M.C.; Sallman, D.A.; Sweet, K.L.; Rizzieri, D.A.; Sayre, P.H.; Advani, A.S.; Emadi, A.; Wieduwilt, M.J.; et al. Flotetuzumab, an Investigational CD123 x CD3 Bispecific Dart ${ }^{\circledR}$ Protein, in Salvage Therapy for Primary Refractory and Early Relapsed Acute Myeloid Leukemia (AML) Patients. Blood 2019, 134 (Suppl. 1), 733. [CrossRef]

139. Wei, A.H.; Fong, C.Y.; Montesinos, P.; Calbacho, M.; Gil, J.S.; Perez De Oteyza, J.; Rowe, J.M.; Wolach, O.; Ofran, Y.; Moshe, Y.; et al. A Phase 1 Study of Flotetuzumab, a CD123 x CD3 DART ${ }^{\circledR}$ Protein, Combined with MGA012, an Anti-PD-1 Antibody, in Patients with Relapsed or Refractory Acute Myeloid Leukemia. Blood 2019, 134 (Suppl. 1), 2662. [CrossRef]

140. Budde, L.; Song, J.Y.; Kim, Y.; Blanchard, S.; Wagner, J.; Stein, A.S.; Weng, L.; Del Real, M.; Hernandez, R.; Marcucci, E.; et al. Remissions of Acute Myeloid Leukemia and Blastic Plasmacytoid Dendritic Cell Neoplasm Following Treatment with CD123-Specific CAR T Cells: A First-in-Human Clinical Trial. Blood 2017, 130 (Suppl. 1), 811. [CrossRef]

141. Loff, S.; Dietrich, J.; Meyer, J.E.; Riewaldt, J.; Spehr, J.; von Bonin, M.; Gründer, C.; Swayampakula, M.; Franke, K.; Feldmann, A.; et al. Rapidly Switchable Universal CAR-T Cells for Treatment of CD123-Positive Leukemia. Mol. Oncolytics 2020, 17, 408-420. [CrossRef]

142. Ma, H.; Padmanabhan, I.S.; Parmar, S.; Gong, Y. Targeting CLL-1 for acute myeloid leukemia therapy. J. Hematol. Oncol. 2019, 12, 41. [CrossRef] [PubMed]

143. Bowman, M.R.; Crimmins, M.A.; Yetz-Aldape, J.; Kriz, R.; Kelleher, K.; Herrmann, S. The cloning of CD70 and its identification as the ligand for CD27. J. Immunol. 1994, 152, 1756-1761. [PubMed]

144. Riether, C.; Pabst, T.; Höpner, S.; Bacher, U.; Hinterbrandner, M.; Banz, Y.; Müller, R.; Manz, M.G.; Gharib, W.H. David Francisco, Targeting CD70 with cusatuzumab eliminates acute myeloid leukemia stem cells in patients treated with hypomethylating agents. Nat. Med. 2020, 26, 1459-1467. [CrossRef] [PubMed]

145. Yabushita, T.; Satake, H.; Maruoka, H.; Morita, M.; Katoh, D.; Shimomura, Y.; Yoshioka, S.; Morimoto, T.; Ishikawa, T. Expression of multiple leukemic stem cell markers is associated with poor prognosis in de novo acute myeloid leukemia. Leuk. Lymphoma 2018, 59, 2144-2151. [CrossRef] [PubMed]

146. Van Rhenen, A.; Moshaver, B.; Kelder, A.; Feller, N.; Nieuwint, A.W.M.; Zweegman, S.; Ossenkoppele, G.J.; Schuurhuis, G.J. Aberrant marker expression patterns on the CD34+CD38- stem cell compartment in acute myeloid leukemia allows to distinguish the malignant from the normal stem cell compartment both at diagnosis and in remission. Leukemia 2007, 21, 1700-1707. [CrossRef] [PubMed]

147. Bonardi, F.; Fusetti, F.; Deelen, P.; van Gosliga, D.; Vellenga, E.; Schuringa, J.J. A proteomics and transcriptomics approach to identify leukemic stem cell (LSC) markers. Mol. Cell. Proteom. 2013, 12, 626-637. [CrossRef]

148. Raffel, A.S.; Klimmeck, D.; Falcone, M.; Demir, A.; Straße, W. Quantitative Proteomics Reveals Specific Metabolic Features of Acute Myeloid Leukemia Stem Cells; Heidelberg Institute for Stem Cell Technology and Experimenta: Heidelberg, Germany, 2020.

Publisher's Note: MDPI stays neutral with regard to jurisdictional claims in published maps and institutional affiliations. 